\title{
Synthesis and Structure-Affinity
} Relationship of Small Molecules for Imaging Human CD80 by Positron Emission Tomography

\section{Journal Article}

\section{Author(s):}

Taddio, Marco F.; Mu, Linjing (D); Castro Jaramillo, Claudia Adriana (D); Bollmann, Tanja; Schmid, Dominik M.; Muskalla, Lukas P.; Gruene, Tim; Chiotellis, Aristeidis; Ametamey, Simon M.; Schibli, Roger; Krämer, Stefanie D.

\section{Publication date:}

2019-09-12

\section{Permanent link:}

https://doi.org/10.3929/ethz-b-000365012

\section{Rights / license:}

In Copyright - Non-Commercial Use Permitted

\section{Originally published in:}

Journal of Medicinal Chemistry 62(17), https://doi.org/10.1021/acs.jmedchem.9b00858

\section{Funding acknowledgement:}

153352 - Imaging immunogenic hot-spots in disease with PET by targeting the co-stimulatory molecule CD80 (B7-1) (SNF) 179238 - Optimization of a small-molecule tracer for the imaging of human CD80 by Positron Emission Tomography (PET) (SNF) 


\title{
SYNTHESIS AND STRUCTURE AFFINITY RELATIONSHIP OF SMALL MOLECULES FOR IMAGING HUMAN CD80 BY POSITRON EMISSION TOMOGRAPHY
}

\author{
Marco F. Taddio ${ }^{1 *}$, Linjing Mu ${ }^{1,2}$, Claudia A. Castro Jaramillo ${ }^{1}$, Tanja Bollmann ${ }^{1}$, Dominik \\ Schmid $^{1}$, Lukas Muskalla ${ }^{3}$, Tim Grüne ${ }^{3,4}$, Aristeidis Chiotellis ${ }^{1}$, Simon M. Ametamey ${ }^{l}$, Roger \\ Schibli ${ }^{1}$, Stefanie D. Krämer ${ }^{*}$
}

${ }^{1}$ Center for Radiopharmaceutical Sciences ETH, PSI and USZ, Department of Chemistry and Applied Biosciences, ETH Zurich, CH-8093 Zurich, Switzerland; ${ }^{2}$ Department of Nuclear Medicine, University Hospital Zurich, CH-8091 Zurich, Switzerland; ${ }^{3}$ Laboratory for Catalysis and Sustainable Chemistry, Paul Scherrer Institute, CH-5232 Villigen PSI, Switzerland; ${ }^{4}$ X-ray Structure Analysis Centre, Faculty of Chemistry, University of Vienna, A-1090 Vienna, Austria

Keywords: CD80 / imaging / inflammation / PET / small molecules

This document is the unedited Author's version of a Submitted Work that was subsequently accepted for publication in the Journal of Medicinal Chemistry, copyright (C) American Chemical Society after peer review. To access the final edited and published work see https://pubs.acs.org/doi/10.1021/acs.jmedchem.9b00858.

\begin{abstract}
The co-stimulatory molecule CD80 is an early marker for immune activation. It is upregulated on activated antigen-presenting cells. We aimed at developing a tracer for imaging CD 80 by positron emission tomography (PET). Novel CD80 ligands were synthesized and tested by SPR for affinity to human CD80 (hCD80) and displacement of endogenous ligands. Several compounds bound with one-digit nanomolar affinity to hCD80 and displaced CTLA-4 and CD28 at nanomolar concentrations. A structure-affinity relationship study revealed relevant moieties for strong affinity to hCD80 and positions for further modifications. Lead compound MT107 (7f) was radiolabelled with carbon-11. In vitro, $\left[{ }^{11} \mathrm{C}\right] \mathrm{MT} 107$ showed specific binding to hCD80-positive tissue and high plasma protein binding. In vivo, $\left[{ }^{11} \mathrm{C}\right] \mathrm{MT} 107$ accumulated in liver, gall bladder and intestines, but only scarcely in hCD80-positive xenografts. The unfavourable in vivo performance may result from high plasma protein binding and extensive biliary excretion.
\end{abstract}




\section{ABSTRACT}

The co-stimulatory molecule CD80 is an early marker for immune activation. It is upregulated on activated antigen-presenting cells. We aimed at developing a tracer for imaging CD80 by positron emission tomography (PET). Novel CD80 ligands were synthesized and tested by SPR for affinity to human CD80 (hCD80) and displacement of endogenous ligands. Several compounds bound with one-digit nanomolar affinity to hCD 80 and displaced CTLA-4 and CD28 at nanomolar concentrations. A structure-affinity relationship study revealed relevant moieties for strong affinity to hCD80 and positions for further modifications. Lead compound MT107 (7f) was radiolabelled with carbon-11. In vitro, $\left[{ }^{11} \mathrm{C}\right] \mathrm{MT} 107$ showed specific binding to hCD80-positive tissue and high plasma protein binding. In vivo, $\left[{ }^{11} \mathrm{C}\right] \mathrm{MT} 107$ accumulated in liver, gall bladder and intestines, but only scarcely in hCD80-positive xenografts. The unfavourable in vivo performance may result from high plasma protein binding and extensive biliary excretion. 


\section{INTRODUCTION}

The co-stimulatory molecules CD80 (B7-1) and CD86 (B7-2) are expressed on activated antigenpresenting cells. They interact with immune-modulatory molecules on T cells, among them CTLA4 and CD28. The weak-affinity interaction of CD80 or CD86 with CD28 is involved in T-cell activation, while the strong interaction of CD80/CD86 with CTLA-4 prevents T-cell activation. ${ }^{1,2,3}$ The balance between $\mathrm{T}$ cell activation and inactivation is disturbed in various diseases including cancer $^{4}$, atherosclerosis ${ }^{5,6}$, autoimmune diseases ${ }^{7}$ and transplant rejection ${ }^{8}$. Several therapeutic strategies aim at modulating the levels or functions of the co-stimulatory molecules accordingly. CD80/CD86 and their receptors are targeted by immunotherapies for various indications..$^{9,10}$ However, following their dual functionality, finding the right balance in CD80/CD86 modulation remains challenging. Diagnosis, disease staging and therapy planning may benefit from a noninvasive method to detect and quantify T-cell activating co-stimulatory molecules in tissue.

Several fusion proteins are on the market which bind to CD80 and CD86 with strong affinity leading to co-stimulation blockade and anergy of T cells. Abatacept and belatacept are successfully used in rheumatoid arthritis ${ }^{9,10}$ and for the prophylaxis of organ rejection in transplantation medicine, respectively. ${ }^{11,12}$ Both are fusion proteins of the extracellular domain of CTLA-4 and the IgG Fc part. Belatacept contains two pointmutations in the binding domains which result in a 2-fold stronger affinity to human CD80 and a 4-fold stronger affinity to human CD86 as compared to abatacept. ${ }^{11}$

Low molecular weight compounds with strong affinities to CD80 were developed to overcome the drawback of negligible oral bioavailability of the fusion proteins. ${ }^{13,14,15,16}$ Erbe et al. discovered a binding site for small molecules on human CD80 (hCD80) which is adjacent to the binding domains for CTLA-4 and CD28, respectively. ${ }^{13}$ The small-molecule binding site is absent on 
rodent CD80 as concluded from both the amino acid sequence and absence of strong-affinity binding of the low molecular weight ligands of hCD80. ${ }^{13}$ In the year 2004, Huxley et al. published structures with strong affinities and high selectivity for hCD80 over hCD86. ${ }^{15}$

Previous work from our group with a carbon-11 labelled radiotracer $\left(\left[{ }^{11} \mathrm{C}\right] \mathrm{AM} 7\right)$, based on the lead structure from Huxley et al. ${ }^{15}$ (1 in Fig. 1), showed promising results in in vitro autoradiography experiments with hCD80-positive xenograft and human atherosclerotic plaque tissue slices. However, it had unfavourable pharmacokinetic properties in mice with high plasma protein binding (human and mouse) and substantial biliary excretion. In vivo accumulation in a hCD80positive xenograft was poor. ${ }^{6}$

In this study, we explored the potential of structurally modified CD80 ligands for the development of a PET tracer with altered pharmacokinetics. We increased the structural diversity by hybridisation of the lead structures introduced by Huxley et al. ${ }^{15}$ and Green et al. ${ }^{14}$ and investigated the structure-affinity relationship of the new compounds by surface plasmon resonance (SPR). A ligand combining core-structure modifications and strong affinity was labelled with carbon-11 and evaluated by PET/CT in mice with hCD80-positive Raji xenografts. 


\section{RESULTS}

Chemistry. A cinnoline-based compound $(\mathbf{1})^{15}$ and pyrazolopyridine-based compounds $(\mathbf{2}, \mathbf{3})^{14}$ were previously reported as potent small molecule ligands for hCD80. Based on these core structures, we designed and synthesized novel cinnoline-, quinoline- and pyrazolopyridine-based compounds in this work. Replacement of the methyl-pyrazole moiety of compound 2 with the benzene ring of compound $\mathbf{1}$ led to novel quinoline-based compounds $\mathbf{7 e - g}$ (Figure 1). The acid intermediates were included for comparison with the acid compound 3 .

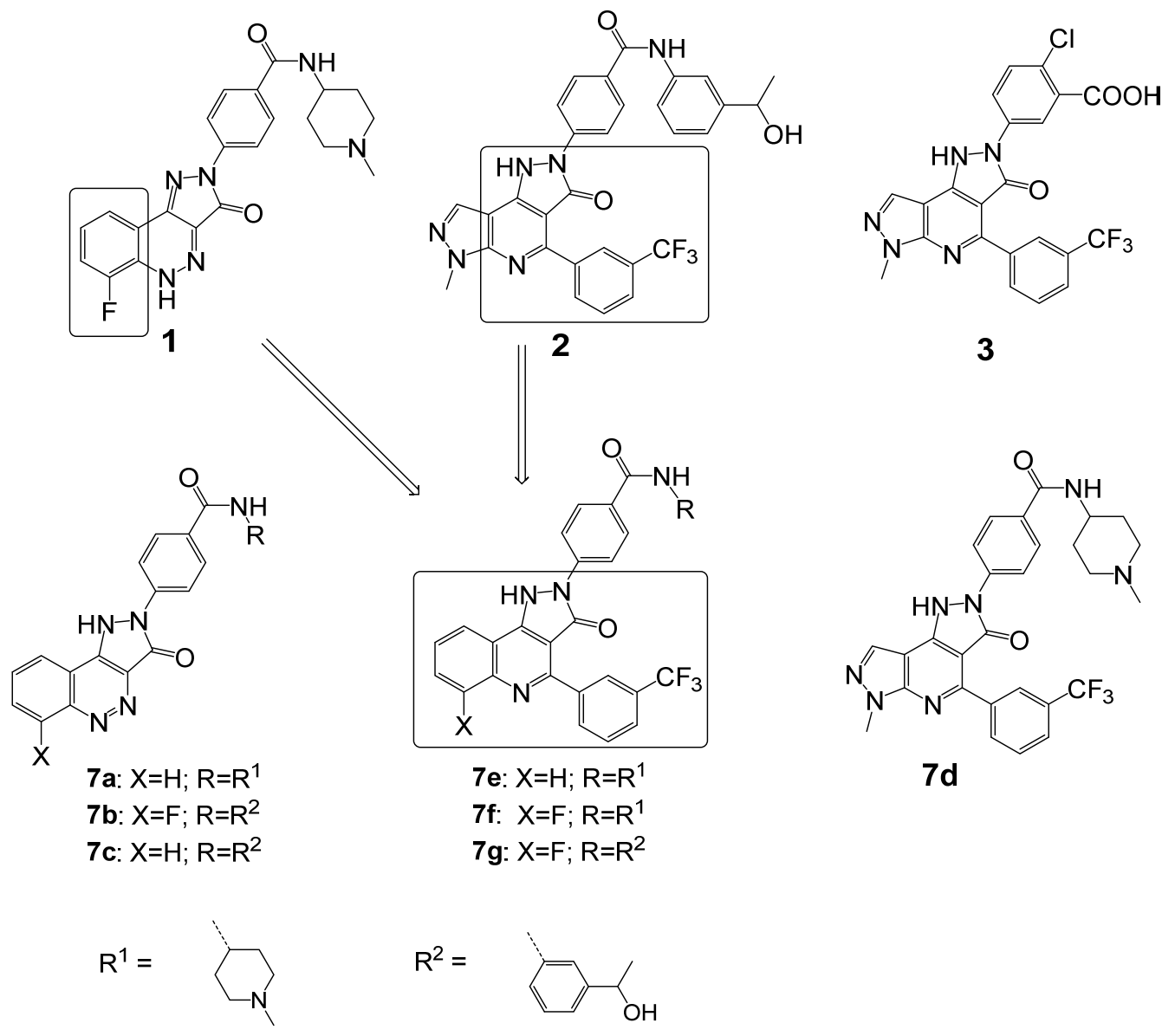


Figure 1. Structures of the synthesized compounds. Boxes indicate structural features from reported compounds $(\mathbf{1} \& \mathbf{2})$ which were conserved in hybrid compounds $\mathbf{7 e}-\mathbf{7 g}$.

Three series of cinnoline-, quinoline- and pyrazolopyridine-based compounds were synthesized based on the modified synthetic procedures as previously described. ${ }^{14,15}$ Scheme 1 depicts the synthetic route for cinnoline-based compounds. Compounds $\mathbf{5 a}$ and $\mathbf{5 b}$ were synthesized by reacting their corresponding phenylhydrazonomalonic acid with thionylchloride, cyclization and methyl ester formation in the presence of $\mathrm{TiCl}_{4}$ and methanol. Converting the hydroxyl group to the chlorinated intermediate, then reacting with 4-hydrazino-benzoic acid formed the key acid compounds $\mathbf{6 a}$ and $\mathbf{6 b}$ in more than $75 \%$ yields. Subsequently, coupling with 1-methylpiperidin4-amine or 1-(3-aminophenyl)ethan-1-ol afforded compounds $\mathbf{1}$ and 7a-c in moderate yields.

Scheme 1: Synthetic pathway towards cinnoline-based compounds.
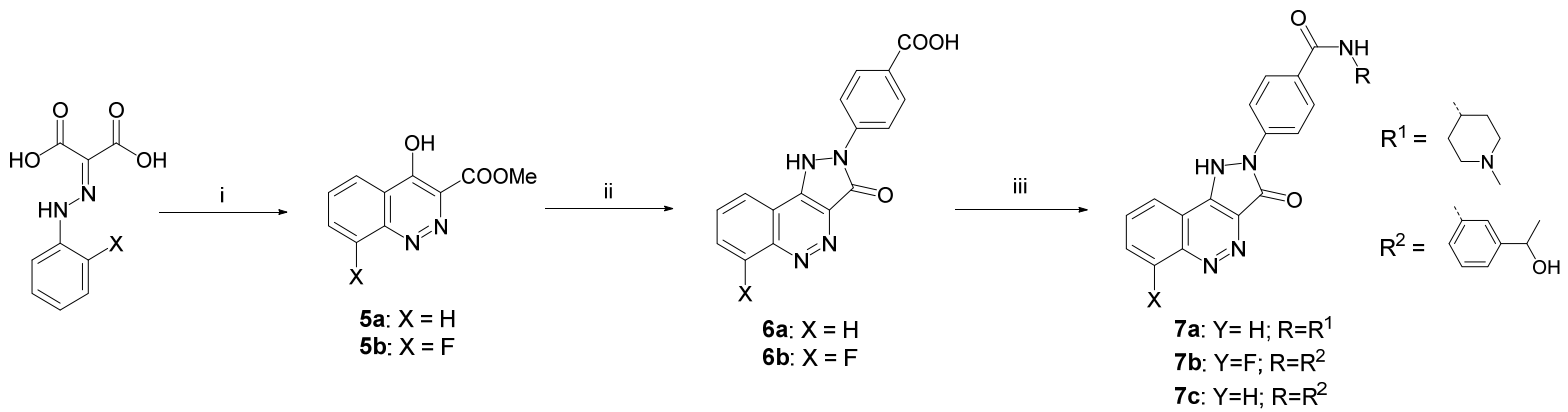

Reagents and conditions: (i) 1) $\mathrm{SOCl}_{2}, 80^{\circ} \mathrm{C}$; 2) $\mathrm{TiCl}_{4}, 110^{\circ} \mathrm{C}$; 3) $\mathrm{MeOH}, 60^{\circ} \mathrm{C}$; (ii) 1) $\mathrm{SOCl}_{2}$, $80^{\circ} \mathrm{C}, 1 \mathrm{~h}$; 2) 4-hydrazinylbenzoic acid, $70^{\circ} \mathrm{C}, \mathrm{EtOH}, 1 \mathrm{~h}$; (iii) R-NH , EDC, DIPEA, rt, DMF, 18 h. $\mathrm{R}^{1}, \mathrm{R}^{2}$, see Figure 1 . 
The pyrazolopyridine- and quinoline-based compounds were synthesized as illustrated in Scheme 2 and 3, respectively. Compound 4 was synthesized by heating ethyl 3-(trifluoromethyl)benzoate in EtOAc with sodium hydride and subsequent methylation with trimethylsilyldiazomethane at room temperature with $48 \%$ yield. Gould-Jacobs cyclisation with ethyl 3-methoxy-3-(3(trifluoromethyl)phenyl)acrylate (4) under strong basic conditions, followed by substitution of the hydroxy group by chlorine using phosphorous oxychloride, afforded 1-methyl-1H-pyrazolo[3,4b]pyridine (5c) or quinolines (5d, 5e) with 55-61\% yields. Subsequent Knorr pyrazole ring formation with hydrazinyl benzoic acid derivatives under basic conditions and heating afforded compounds $6 \mathbf{c}-\mathbf{e}$ in $66-85 \%$ and compound 3 in $31 \%$ yield. In the last step, the carboxylic acid was activated with a coupling reagent (EDC hydrochloride or HATU) and two different building blocks (meta-1-hydroxyethyl-phenyl or para-1-methylpiperidinyl) were introduced by amide bond formation in $13-87 \%$ yields $(\mathbf{2}, \mathbf{7 d - g})$.

Scheme 2: Synthetic route for pyrazolopyridine-based compound 7d.

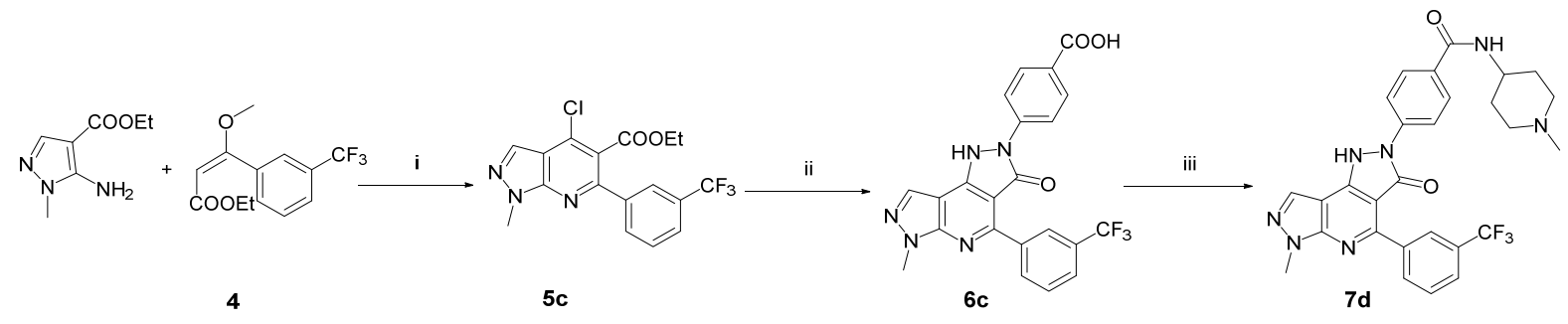

Reagents and conditions: (i) 1) $\mathrm{NaH}$, reflux, THF, $16 \mathrm{~h}$; 2) $\mathrm{POCl} 3,120^{\circ} \mathrm{C}, 2 \mathrm{~h}$; (ii) 4-hydrazinylbenzoic acid, $\mathrm{NaOtBu}, 100^{\circ} \mathrm{C}$, ethylene glycol, $18 \mathrm{~h}$; (iii) 1-methylpiperidin-4amine, EDC, DIPEA, rt, DMF, $18 \mathrm{~h}$ 
Scheme 3: Synthetic pathway toward quinoline-based compounds.

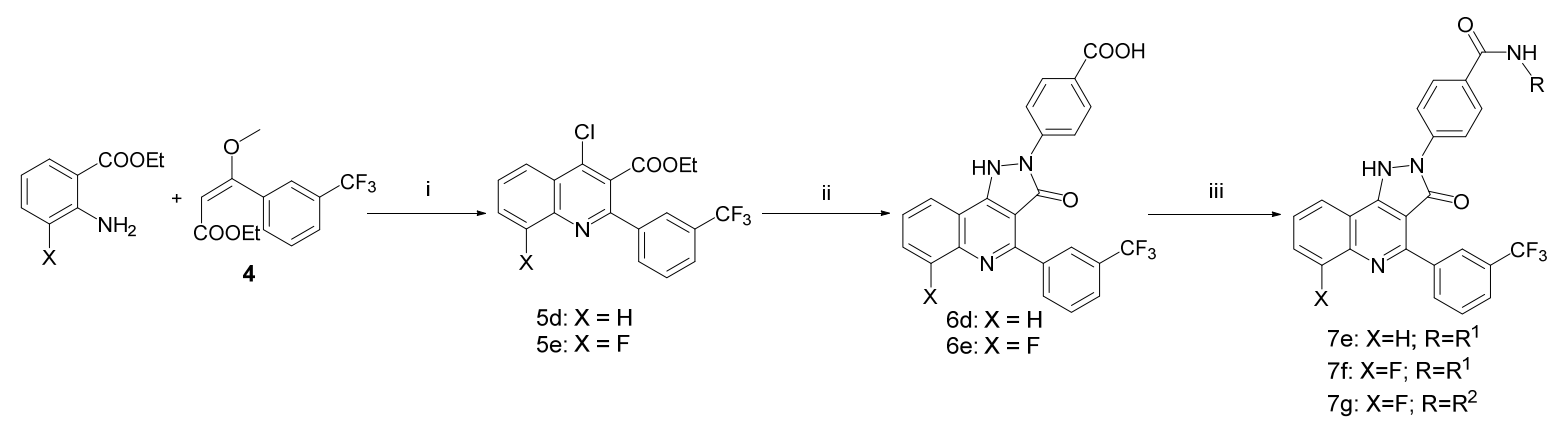

Reagents and conditions: (i) 1) $\mathrm{NaH}$, reflux, THF, $16 \mathrm{~h}$; 2) $\mathrm{POCl}_{3}, 120^{\circ} \mathrm{C}, 2 \mathrm{~h}$;

(ii) 4-hydrazinylbenzoic acid, $\mathrm{NaO}^{\mathrm{t}} \mathrm{Bu}, 100^{\circ} \mathrm{C}$, ethylene glycol, $18 \mathrm{~h}$; (iii) $\mathrm{R}-\mathrm{NH}_{2}, \mathrm{HATU}, \mathrm{DIPEA}$, rt, DMF, 30 min. $\mathrm{R}^{1}, \mathrm{R}^{2}$, see Figure 1 . 
Table 1: Synthesized compounds (structures and substituents according to Figure 1 and Scheme 1) and their affinity to hCD80 determined by surface plasmon resonance.

\begin{tabular}{|c|c|c|c|}
\hline Compound & $\mathbf{X}$ & $\mathbf{R}$ & $K_{\mathrm{d}} \pm \mathrm{SD}[\mathrm{nM}](n)$ \\
\hline 1 (AM7) & $\mathrm{F}$ & $\mathrm{R}^{1}$ & $3.8 \pm 2.5$ \\
\hline 2 & - & $\mathrm{R}^{2}$ & $142 \pm 61$ \\
\hline 3 & - & - & $90.7,48.4$ (2) \\
\hline $6 \mathbf{a}$ & $\mathrm{H}$ & - & 572,368 \\
\hline $6 b$ & $\mathrm{~F}$ & - & n.d. \\
\hline $6 c$ & - & - & 308,397 \\
\hline 6d & $\mathrm{H}$ & - & $194(1)$ \\
\hline $6 e$ & $\mathrm{~F}$ & - & n.d. \\
\hline $7 \mathbf{a}$ & $\mathrm{H}$ & $\mathrm{R}^{1}$ & $9.3,10.7(2)$ \\
\hline $7 b$ & $\mathrm{~F}$ & $\mathrm{R}^{2}$ & $120,72(2)$ \\
\hline $7 c$ & $\mathrm{H}$ & $\mathrm{R}^{2}$ & 117,310 \\
\hline $7 d$ & - & $\mathrm{R}^{1}$ & $109 \pm 10$ \\
\hline $7 e$ & $\mathrm{H}$ & $\mathrm{R}^{1}$ & $7.1,6.5(2)$ \\
\hline 7f (MT107) & $\mathrm{F}$ & $\mathrm{R}^{1}$ & $4.2 \pm 2.3(9)$ \\
\hline $7 \mathrm{~g}$ & $\mathrm{~F}$ & $\mathrm{R}^{2}$ & $113 \pm 50$ \\
\hline
\end{tabular}


$(n)$, number of experiments; SD, standard deviation; n.d., not determined. $K_{\mathrm{d}}$ values of individual experiments are shown for $\mathrm{n} \leq 2 . \mathrm{R}^{1}, \mathrm{R}^{2}$, see Figure 1 .

Binding to hCD80. After the synthesis of the unlabelled compounds in Table 1, we investigated their affinity and kinetics for the binding to recombinant hCD80 (rhCD80) by SPR. Typical binding curves are shown in Supplementary Figure S1. The calculated binding rate constant $\left(k_{o n}\right)$ ranged from $9 \times 10^{4}$ to $7 \times 10^{5} \mathrm{M}^{-1} \mathrm{~s}^{-1}$. The dissociation rate constant $\left(k_{\text {off }}\right)$ ranged from $4 \times 10^{-4}$ to 0.4 $\mathrm{s}^{-1}$ and $K_{\mathrm{d}}$ from 3.8 to $572 \mathrm{nM}$ (Table 1 ). In order to reach high signal ratios between hCD80positive and negative tissues in PET imaging, we aimed at a strong affinity (low $K_{\mathrm{d}}$ ) with a low $k_{\text {off. }}$ This is the case for compounds in the right upper corner in the plot $1 / K_{\mathrm{d}} v_{s} 1 / k_{\text {off }}$ in Figure 2 $(1,7 a, 7 e, 7 f)$. 


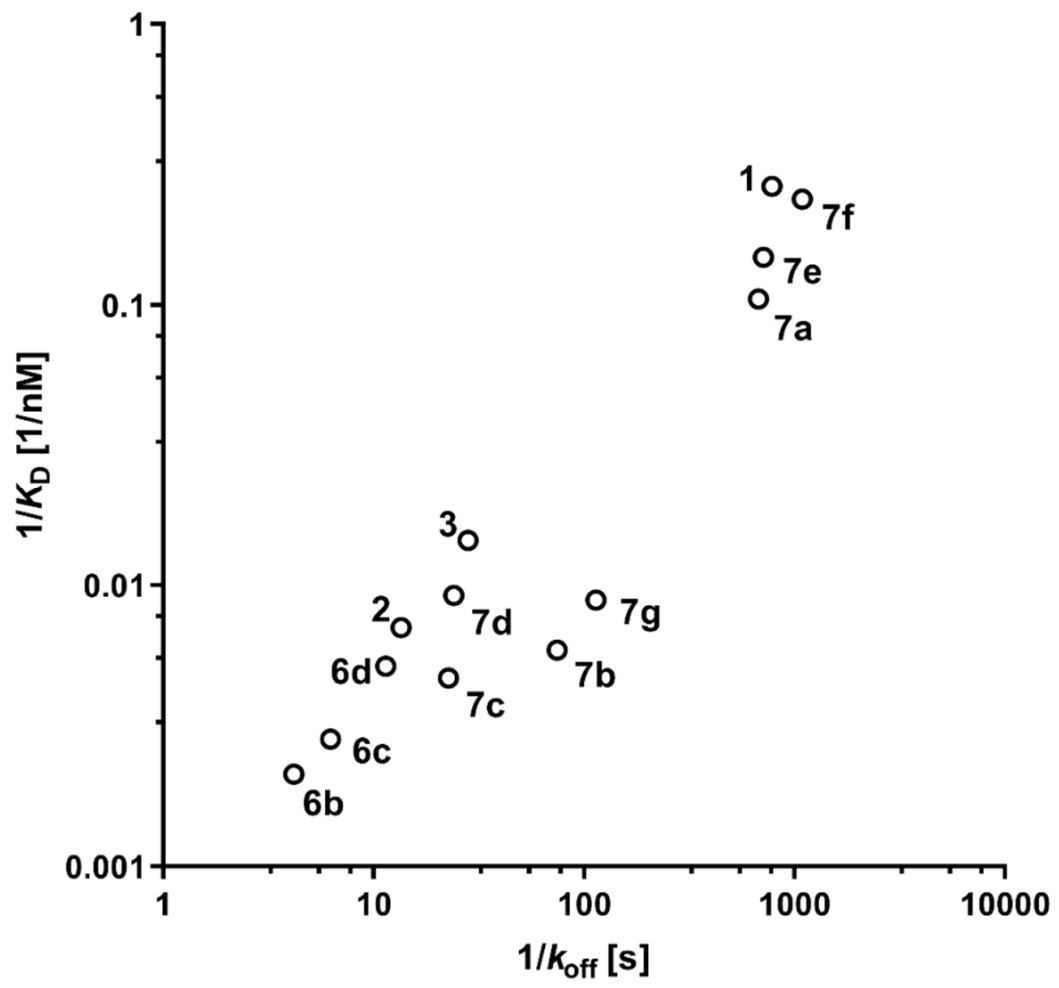

Figure 2. $1 / K_{\mathrm{d}}$ plotted against $1 / k_{\mathrm{off}}$ from SPR experiments. Compounds with preferred binding properties for PET imaging are in the upper right corner (low $K_{\mathrm{d}}$, low $k_{\mathrm{off}}$ ).

Displacement of hCTLA-4 and hCD28 from hCD80 binding. We next investigated by SPR the potential of $\mathbf{1 , 2}$ and $\mathbf{7 f}$ for displacing the binding domains of hCTLA-4 (in our study abatacept) and rhCD28 from the binding to rhCD80. We first confirmed published $K_{\mathrm{d}}$ values of rhCTLA-4 $(0.27 \mathrm{nM})$ and $\mathrm{rhCD} 28(16.3 \mathrm{nM})$ to $\mathrm{rhCD} 80 .{ }^{17}$ In our assay, they were $0.5 \mathrm{nM}$ and $17.8 \mathrm{nM}$, respectively $(n=1)$. For the displacement assay, we used abatacept and rhCD28 at concentrations 3-4-fold above their $K_{\mathrm{d}}$ values, i.e., $2 \mathrm{nM}$ and $50 \mathrm{nM}$, respectively. According to the Cheng-Prusoff equation, keeping a constant ratio between concentration and $K_{\mathrm{D}}$ of a displaced ligand (abatacept) should result in similar $\mathrm{IC}_{50}$ values for a particular displacer compound in varying experiments. 
The displacement of abatacept was most effective by $\mathbf{1}$ and $\mathbf{7 f}$ with $\mathrm{IC}_{50}$ values around $15 \mathrm{nM}$ (Figure 3). The $\mathrm{IC}_{50}$ was more than one magnitude higher for $\mathbf{2}$. The $\mathrm{IC}_{50}$ values for the displacement of rhCD28 were around $10 \mathrm{nM}$ for $\mathbf{1}$ and $\mathbf{7 f}$, as shown in Figure 3 (not determined for 2). The respective $K_{\mathrm{i}}$ values calculated from these data are shown in Figure 3 . The $K_{\mathrm{i}}$ determined in the displacement experiments were in agreement with the $K_{\mathrm{d}}$ values determined in the direct binding experiments (Table 1). Furthermore, 7f competed only weakly (at concentrations $>50 \mu \mathrm{M}$ ) with the binding of abatacept to rhCD86 and recombinant murine CD80 (rmCD80), in agreement with its selectivity for hCD80 over hCD86 and mCD80 (Supplementary Figures S2 and S3). 

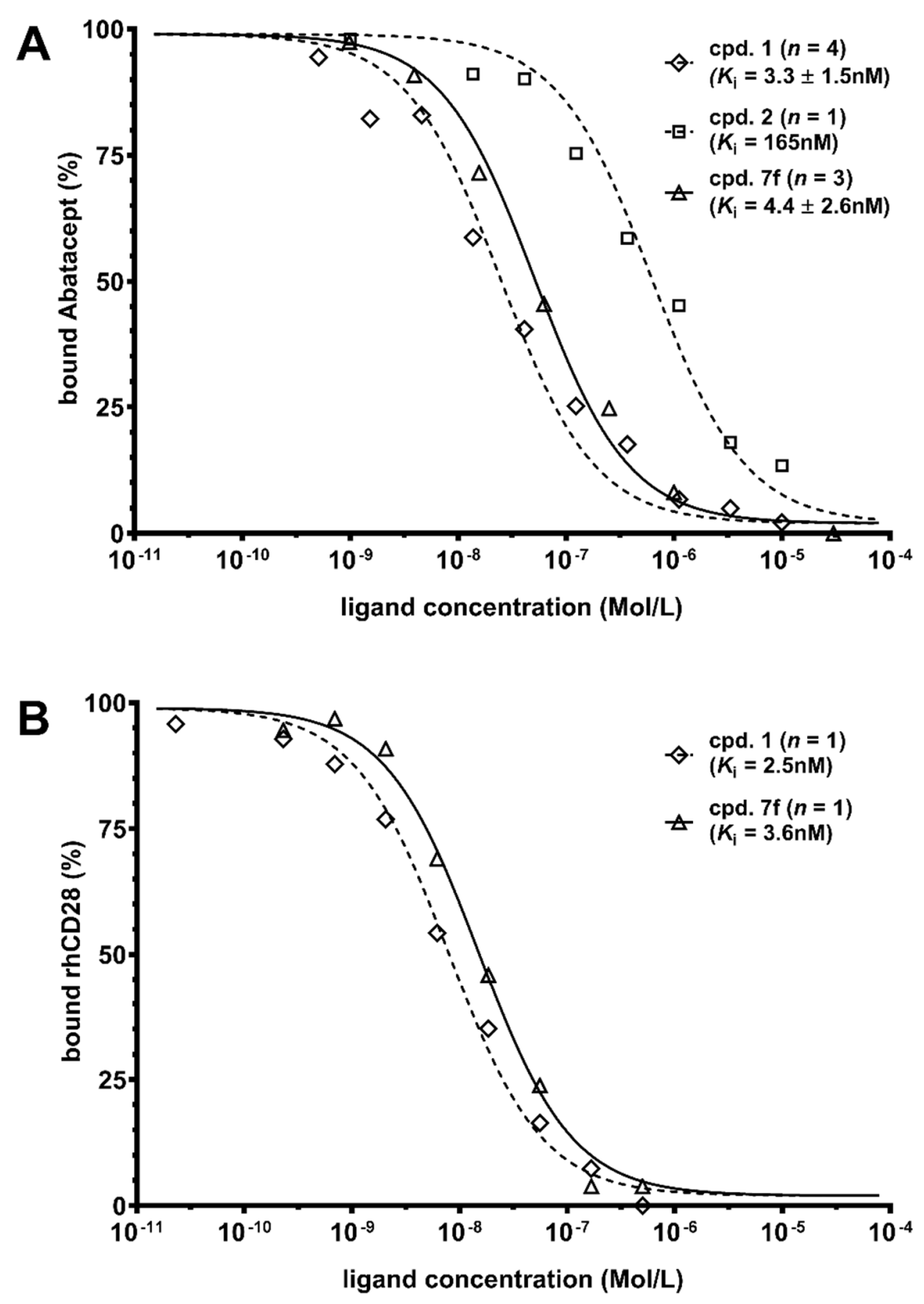

Figure 3: Representative displacement curves of (A) $2 \mathrm{nM}$ abatacept or (B) $50 \mathrm{nM}$ rhCD28 from immobilized rhCD80 by small molecules $\mathbf{1 , 2}$ (only in $\mathbf{A}$ ) or $\mathbf{7 f}$. IC 50 values were determined from the displacement by different concentrations of synthesized small molecules (x axis) assuming 1:1 binding stoichiometries. The respective (averaged) $K_{\mathrm{i}}$ values $( \pm$ S.D. for $\mathrm{n} \geq 3$ ) are indicated in the Figure. $n$, number of experiments for $K_{\mathrm{i}}$ determination. 
Radiosynthesis of $\left[{ }^{11} \mathbf{C}\right] \mathbf{1}$ and $\left[{ }^{11} \mathbf{C}\right] 7 \mathbf{f}$. Precursor compounds for radiolabelling were synthesized from intermediates $\mathbf{6 b}$ and $\mathbf{6 e}$ (shown in Scheme 1 and 3, respectively). By activation of the carboxylic acid with the coupling reagent EDC and following amide bond formation 1-bocpiperidin-4-amine under basic conditions, a boc-protected piperidine was introduced which was subsequently deprotected with DCM/TFA to afford compounds $\mathbf{8 a}$ and $\mathbf{8 b}$ in good yields (details in experimental section). Our group recently described the radiolabelling procedure of $\mathbf{1}$ with carbon-11 (ref. 6). This procedure was applied for the radiosynthesis of both $\left[{ }^{11} \mathrm{C}\right] \mathbf{1}$ and our new radiotracer $\left[{ }^{11} \mathrm{C}\right] 7 \mathbf{f}$. Details on the one-step radiosynthesis are described in the experimental section. Molar activities at the end of synthesis were between 200 and $500 \mathrm{GBq} / \mu \mathrm{mol}$ for $\left[{ }^{11} \mathrm{C}\right] \mathbf{1}$ and between 20 and $80 \mathrm{GBq} / \mu \mathrm{mol}$ for $\left[{ }^{11} \mathrm{C}\right] 7 \mathbf{f}$.

Lipophilicity, membrane permeability \& plasma protein binding. In vivo, $\left[{ }^{11} \mathrm{C}\right] 1$ scarcely distributed to the tissue, in agreement with its $\operatorname{low} \log D$ at $\mathrm{pH} 7.4$ of 0.1 and its low free fraction in plasma of $0.02 .{ }^{6}$ We determined $\log D$ of $\left[{ }^{11} \mathrm{C}\right] 7 \mathbf{f}$ at various $\mathrm{pH} .7 \mathbf{f}$ differs from $\mathbf{1}$ by the $\mathrm{C}$-[3(trifluoromethyl)phenyl] moiety replacing the nitrogen in position 2 of the cinnoline substructure (Figure 1 and Table 1). As expected, this modification rendered the compound more lipophilic, with a $\log D$ at $\mathrm{pH} 7.4$ of $1.98 \pm 0.06$. The $\log D$ was significantly lower at $\mathrm{pH} 5.4$ than at higher $\mathrm{pH}$ values (Supplementary Figure S4). This is in agreement with the distribution characteristics of a basic compound (tertiary amine in $\mathrm{R}^{2}$, Figure 1 ). The fit $\log P$ was 2.1 with a fit $\mathrm{p} K_{\mathrm{a}}$ of 7.1 .

We furthermore investigated the potential of the synthetized compounds $\mathbf{1}, \mathbf{2}, \mathbf{7 e}, \mathbf{7} \mathbf{f}$ and $\mathbf{7 g}$ to cross lipid bilayers at $\mathrm{pH} 7.4$, using a recently introduced liposomal fluorescent permeability assay. ${ }^{18}$ 
The logarithmic permeability coefficients, $\log \left(P_{\mathrm{FLipP}}, \mathrm{cm} / \mathrm{s}\right)$, ranged from -6.7 to -5.4 , indicating poor to moderate membrane permeability. ${ }^{18}$ Permeation kinetics were fastest for $\mathbf{1}, \mathbf{7 e}$ and $\mathbf{7 f}$ with $\log P_{\text {FLipP }}$ above -6.

The plasma protein binding of $\left[{ }^{11} \mathrm{C}\right] 7 \mathbf{f}$ was investigated with human plasma and bovine serum albumin (BSA) using ultracentrifugation filter units. The free fraction was $0.023 \pm 0.002(n=4)$ for human plasma which is similar to the plasma protein binding of $\left[{ }^{11} \mathrm{C}\right] \mathbf{1}^{6}$, and a higher free fraction for BSA of $0.159 \pm 0.002(n=3)$.

In vitro autoradiography. We chose compound $7 \mathbf{f}$ for further in vitro and in vivo evaluation based on its strong binding affinity to hCD80 (low $K_{\mathrm{d}}$ ) at low $k_{\text {off }}$ (Figure 2 and Supplementary Figure S1) and as it differed from $\mathbf{1}$ in at least one physicochemical property (higher lipophilicity). Structural modifications with higher predicted impact on the physicochemical properties (e.g., protonation/deprotonation equilibria) resulted in weakened binding affinity (Figures 1, 2 and Table 1). In vitro autoradiography with $\left[{ }^{11} \mathrm{C}\right] 7 \mathbf{f}$ revealed higher accumulation on tissue slices of hCD80-positive Raji than hCD80-negative NCI-H69 xenografts (Supplementary Figures S5 and S6). The binding of $\left[{ }^{11} \mathrm{C}\right] 7 \mathbf{f}$ to hCD80-positive Raji xenograft slices was reduced by an excess of $5 \mu \mathrm{M}$ 7f, 1, 2 and abatacept, respectively, by around $35 \%$ of the total binding. No reduction in $\left[{ }^{11} \mathrm{C}\right] 7 \mathbf{f}$ binding was observed with the hCD80-negative tissue slices under these blocking conditions.

In vivo evaluation in Raji xenograft bearing mice. We further evaluated $\left[{ }^{11} \mathrm{C}\right] 7 \mathbf{f}$ in vivo by PET/CT imaging. We have recently compared the in vivo pharmacokinetics of $\left[{ }^{11} \mathrm{C}\right] \mathbf{1}$ and $\left[{ }^{11} \mathrm{C}\right] \mathbf{7 f}$ 
by kinetic modelling with PET data. ${ }^{19}$ Both tracers showed low distribution to tissue, in agreement with the high plasma protein binding, but high extraction into the bile relative to the low free fraction in plasma. This resulted in high abdominal radioactivity with spill-over to peripheral tissues in the PET images. The biliary excretion of $\left[{ }^{11} \mathrm{C}\right] 7 \mathbf{f}$ was significantly reduced by preadministration of cyclosporine, an inhibitor of several hepatic transport proteins. ${ }^{19}$ Here, we evaluated the uptake of $\left[{ }^{11} \mathrm{C}\right] 7 \mathbf{f}$ into the Raji xenografts from the data sets which were used for pharmacokinetic modelling in the previous work. ${ }^{19}$ Figure 4 shows $\left[{ }^{11} \mathrm{C}\right] 7 \mathbf{f}$ PET images of a Raji xenograft bearing SCID mouse after administration of cyclosporine $\sim 30$ min before the tracer. Scarce accumulation of $\left[{ }^{11} \mathrm{C}\right] 7 \mathbf{f}$ in the periphery of the xenograft, as indicated in Figure 4, was observed in two out of four cyclosporine-administered animals. No xenograft accumulation was observed in the four animals without cyclosporine. For comparison, Figure 4 shows in addition a representative $\left[{ }^{18} \mathrm{~F}\right] \mathrm{FDG}$ scan of a Raji-xenograft bearing mouse.

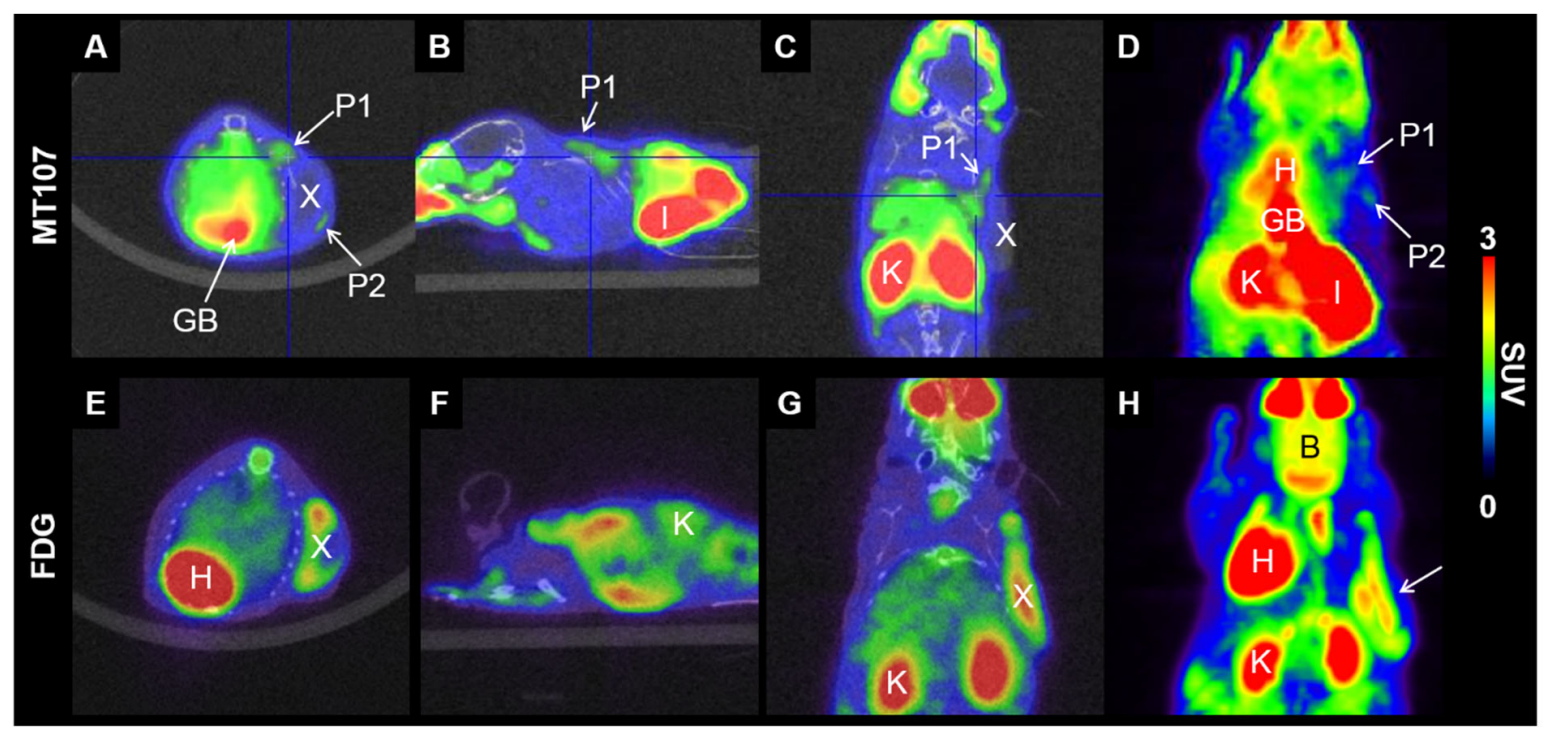

Figure 4: PET/CT images of a Raji (hCD80+) xenograft bearing mouse after tail vein injection of 11.7 MBq (13 nmol/kg) $\left[{ }^{11} \mathrm{C}\right] 7 \mathbf{f}, 30 \mathrm{~min}$ after i.v. injection of $50 \mathrm{mg} / \mathrm{kg}$ cyclosporine (A-D). (E-H) 
For comparison, representative PET/CT images of a Raji (hCD80+) xenograft bearing mouse after tail vein injection of $8.6 \mathrm{MBq}\left[{ }^{18} \mathrm{~F}\right] \mathrm{FDG}$. Transversal $(\mathrm{A}, \mathrm{E})$, sagittal $(\mathrm{B}, \mathrm{F})$ and coronal $(\mathrm{C}, \mathrm{G})$ planes, as indicated by the blue cross hairs. $(\mathrm{D}, \mathrm{H})$ Maximal intensity projection. $\mathrm{CT}$, grey scale; PET, color scale. H, blood pool (heart); GB, gall bladder; I, intestines; K, kidney; B, brain; P1 and P2, peripheral locations of the xenograft with potential tracer accumulation; X, Raji xenograft. SUV, standardised uptake value. Note that this scan was used for pharmacokinetic modelling in our previous work ${ }^{19}$ and that different animals were used for the $\left[{ }^{11} \mathrm{C}\right] 7 \mathbf{f}$ and the $\left[{ }^{18} \mathrm{~F}\right] \mathrm{FDG}$ scan.

In order to evaluate the viability of the tumor cells and their general accessibility by radiotracers, additional mice with Raji xenografts were scanned with the glucose analogue $\left[{ }^{18} \mathrm{~F}\right] \mathrm{FDG} .\left[{ }^{18} \mathrm{~F}\right] \mathrm{FDG}$ uptake was substantial in major parts of the xenografts (Figure 4), confirming the presence of viable tumor tissue. The in vivo expression of hCD80 and its localisation on the cell surface were confirmed by flow cytometry and RT-qPCR (Supplementary Figures S7 and S8).

The metabolic stability of $\left[{ }^{11} \mathrm{C}\right] 7 \mathbf{f}$ was investigated in xenograft-free C57BL/6 mice. Only parent tracer was detected in blood plasma, bile and urine 15 min after tracer i.v. injection (Supplementary Figure S9).

\section{DISCUSSION}

Our SPR data from a set of novel structures revealed that the methylpiperidine moiety is an essential part for the strong binding to hCD80. Compounds with the N-methyl-piperidine moiety $(1,7 a, 7 e, 7 f)$ showed consistently stronger affinities than compounds with the phenylethan-1-ol moiety. In addition, the cinnoline- and quinoline-based structures showed stronger binding than 
the pyrazolopyridine-based structures. The modification with an additional $\mathrm{CF}_{3}$-substituted phenyl ring in position 2 of the quinoline ring system did not affect the binding affinity to hCD80. This suggests that this part of the structure is tolerant for modifications, as was seen for novel structure 7f, which showed similar affinity as $\mathbf{1}$ despite an additional bulky group ( $\mathrm{CF}_{3}$ substituted aromatic ring). Taken together, the structure affinity relationship study with hybrid structures of $\mathbf{1}$ and $\mathbf{2}$ provides new insights in the structural requirements for CD80 binding and indicates that further modifications are possible without affinity loss.

Displacement of rhCTLA-4 and rhCD28 from hCD80 by $\mathbf{1}$ and $\mathbf{7 f}$ showed that this low molecular weight compound class has the potential to displace large proteins from binding to hCD80. This ability may be attained by an allosteric mechanism, due to adjacent binding sites on the tertiary structure of hCD $80 .^{13}$

The experimental $\log D$ at $\mathrm{pH} 7.4$ of $\left[{ }^{11} \mathrm{C}\right] \mathbf{7 f}$ was two $\log$ units higher than that of $\left[{ }^{11} \mathrm{C}\right] \mathbf{1}$. However, lipid bilayer permeation of both compounds $\mathbf{1}$ and $7 \mathbf{f}$ was poor to moderate. In addition, both had similar high plasma protein binding with a free fraction in plasma of $\sim 0.02$ (Müller et $\mathrm{al}^{6}{ }^{6}$ and this study). The free fraction of $\left[{ }^{11} \mathrm{C}\right] 7 \mathbf{f}$ in $4 \%$ BSA was $\sim 0.15$ which indicates that besides albumin an alternative plasma protein may be involved in the binding (assuming binding is similar to human and bovine albumin). This may be $\alpha_{1}$-acid glycoprotein, which binds mainly basic compounds. ${ }^{20}$

The negligible uptake of both $\left[{ }^{11} \mathrm{C}\right] \mathbf{1}$ and $\left[{ }^{11} \mathrm{C}\right] 7 \mathbf{f}$ into the hCD80-positive xenografts may result from the high plasma protein binding, hampering extravasation of the tracers. The small volume of distribution, in particular of $\left[{ }^{11} \mathrm{C}\right] 7 \mathbf{f}\left(14 \%\right.$ of total body volume $\left.{ }^{19}\right)$ supports this hypothesis. The pre-administration of cyclosporine reduced the biliary excretion significantly and in addition increased the volume of distribution and tissue distribution, though without statistical significance ${ }^{19}$. Both the reduction in spill-over from abdominal radioactivity and potential increase 
in tissue distribution may have contributed to the observed increased radioactivity in peripheral parts of the hCD80-rich xenografts in two out of four cyclosporine treated animals.

Biliary excretion as well as strong binding to plasma proteins may depend on the cationic characteristics of the tracers ${ }^{21,22,23,24}$. We currently investigate the effect of the charge and ionization state on the binding affinity to hCD80, biliary excretion, plasma protein binding and finally in vivo imaging.

\section{CONCLUSION}

A structure-affinity relationship study identified structural features which promote low nanomolar affinity to hCD80. Despite strong in vitro binding of $\mathbf{7 f}$ to hCD80, observed by SPR and autoradiography, PET-tracer $\left[{ }^{11} \mathrm{C}\right] 7 \mathbf{f}$ hardly accumulated in hCD80-rich xenografts in vivo. High plasma protein binding and high spill-over due to biliary excretion may have hampered observable accumulation. Further structural modifications towards pharmacokinetic optimisation will be based on these results. Besides imaging, our findings may be of interest for the development of therapeutic CD80 inhibitors. 


\section{EXPERIMENTAL SECTION}

Materials \& methods. All chemicals, unless otherwise stated, were purchased from Sigma Aldrich GmbH (Taufkirchen, Germany), ABCR GmbH (Karlsruhe, Germany), Merck (Darmstadt, Germany), Fluorochem Ltd. (Hadfield, GB), Tokyo Chemical Industry Co. Ltd (Tokyo, Japan), Apollo Scientific Ltd (Cheshire, GB) or Fisher Scientific International Inc. (Hampton, US) and were used without further purification.

Solvents for thin layer chromatography (TLC), column chromatography and extractions were commercial grade. Organic chemistry reactions were monitored by TLC using Sigma-Aldrich silica gel 60 plates (UV light at $254 \mathrm{~nm}$ ). Nuclear magnetic resonance (NMR) spectra $\left({ }^{1} \mathrm{H}\right.$ and ${ }^{13} \mathrm{C}$ NMR) were obtained on a Bruker Avance FT-NMR spectrometer (400 MHz). Chemical shifts are given in delta $(\delta)$ units, in ppm relative to tetramethylsilane (TMS, $0 \mathrm{ppm}$ ). Multiplicities in the ${ }^{1} \mathrm{H}$ NMR spectra are described as: $\mathrm{s}=$ singlet, $\mathrm{d}=$ doublet, $\mathrm{t}=$ triplet and $\mathrm{m}=$ multiplet. Coupling constants $(J)$ are reported in Hz. High resolution mass spectrometry (HR-MS) was performed by the MS service of the Laboratory for Organic Chemistry at the ETH Zürich. The MALDI spectra were recorded on a Bruker solariX (MALDI-FTICR-MS) or Bruker UltraFlex II (MALDI-TOFMS), while the ESI were recorded on a Bruker maXis (ESI-Qq-TOF-MS) or Bruker solariX (ESIFTICR-MS). High-performance liquid chromatography (HPLC) analysis was performed using a reversed phase column (ACE column, $\mathrm{C} 18,3 \mu \mathrm{m}$ ) with a gradient system of acetonitrile and $50 \mathrm{mM}$ sodium acetate. Semi-preparative HPLC purifications were carried out on a reversed phase column (ACE column, Symmetry C8 $5 \mu \mathrm{m} ; 7.8 \times 50 \mathrm{~mm}$ ) under following conditions: $4.1 \mathrm{~g} / \mathrm{L}$ sodium acetate in $\mathrm{H}_{2} \mathrm{O}$ (solvent $\mathrm{A}$ ), $\mathrm{MeCN}$ (solvent $\mathrm{B}$ ); isocratic with $25 \% \mathrm{~B}$; flow rate $4.5 \mathrm{~mL} / \mathrm{min}$. The UV signal was measured at a wavelength of $320 \mathrm{~nm}$. 
The purity of all biologically tested compounds was $\geq 95 \%$, except of intermediate $\mathbf{6 d}$ with a purity of $92 \%$. Purity was determined by HPLC using an analytical reverse phase column (Xbridge, C18, $5 \mu \mathrm{m} ; 4.6 \times 150 \mathrm{~mm}$ ) with $\mathrm{H}_{2} \mathrm{O} / \mathrm{MeCN}$ (both containing $0.1 \% \mathrm{TFA}$ ) as mobile phase. Method: 2 min isocratic 5\% MeCN followed by a gradient from 5\% to $90 \% \mathrm{MeCN}$ in $12 \mathrm{~min}$. Peaks corresponding to the desired product are described, including retention time (rt) and purity by integration.

The recombinant human CTLA-4 fusion protein abatacept (Orencia ${ }^{\circledR}$, Bristol-Myers-Squibb) and cyclosporine (Sandimmun ${ }^{\circledR}$, Novartis) were purchased from a local pharmacy.

All animal experiments were carried out in accordance with the Swiss Animal Welfare legislation and approved by the Veterinary Office of the Canton Zurich (ZH17/2015 and ZH18/2018). Female C.B.17 SCID mice (xenografts) and male C57BL/6 mice (tracer metabolism) were purchased from Charles River Laboratories (Sulzfeld, Germany) and housed under standard conditions (12 h light/12 $\mathrm{h}$ dark, free access to chow and water). $\left[{ }^{18} \mathrm{~F}\right] \mathrm{FDG}$ was generated in a routine production by the University Hospital Zurich.

\section{Chemistry}

\section{4-(6-fluoro-1,3-dihydro-3-oxo-2H-pyrazolo[4,3-c] cinnolin-2-yl)- $N$-(1-methyl-4-piperidinyl)-}

benzamide (1). Compound 1 was synthesised from $\mathbf{6 b}$ following the same experimental procedure like the synthesis of 2 and 1-methylpiperidine-4-amine. MS (ESI) calculated for $\mathrm{C}_{22} \mathrm{H}_{22} \mathrm{FN}_{6} \mathrm{O}_{2}{ }^{+}$: 421.2; $\mathrm{m} / z$ found was $421.2[\mathrm{M}+\mathrm{H}]^{+} ; \mathrm{rt} 9.36 \mathrm{~min}, 95 \%$. 


\section{4-[3,6-dihydro-6-methyl-3-oxo-4-[3-(trifluoromethyl)phenyl]dipyrazolo[3,4-b:3',4'-d]pyri-}

din-2(1H)-yl]- $N$-[3-(1-hydroxyethyl)phenyl]-benzamide (2). $100 \mathrm{mg}(0.22 \mathrm{mmol})$ of $\mathbf{6 c}$ were dissolved in $1.1 \mathrm{~mL}$ DMF and stirred in a round-bottom flask. $93 \mathrm{mg}$ (0.66 mmol) 1-(3aminophenyl)ethan-1-ol, $70 \mu \mathrm{L}(0.40 \mathrm{mmol})$ DIPEA and $85 \mathrm{mg}(0.44 \mathrm{mmol})$ EDC hydrochloride were added and the mixture was stirred for $7 \mathrm{~h}$, before EtOAc and $0.25-\mathrm{M} \mathrm{HCl}$ was added, and extraction was performed. The combined organic layers were washed with brine, dried over sodium sulfate, filtered and concentrated. The crude was purified by flash chromatography (9:1 EtOAc:EtOH saturated with ammonium bicarbonate) and relevant fractions were collected and concentrated, which resulted in a product weight of $78 \mathrm{mg}(62 \%$ yield). HR-MS (ESI) calculated for $\mathrm{C}_{30} \mathrm{H}_{24} \mathrm{~F}_{3} \mathrm{~N}_{6} \mathrm{NaO}_{3}{ }^{+}: 595.1676 ; \mathrm{m} / z$ found was $595.1675[\mathrm{M}+\mathrm{Na}]^{+}$; rt $13.58 \mathrm{~min}, 95 \%$.

\section{2-chloro-5-[3,6-dihydro-6-methyl-3-oxo-4-[3-(trifluoromethyl)phenyl]dipyrazolo[3,4-b:3',} 4'-d]pyridin-2(1H)-yl]-benzoic acid (3). $64 \mathrm{mg}(0.28 \mathrm{mmol})$ of 2-chloro-5-hydrazinylbenzoic acid hydrochloride were dispersed in $480 \mu \mathrm{L}$ ethylene glycol, before $47.4 \mathrm{mg}(0.47 \mathrm{mmol})$ of sodium tert-butoxide were added and the mixture was stirred for $1.5 \mathrm{~h}$ at $75^{\circ} \mathrm{C}$. It was cooled to $\mathrm{rt}$ and $36 \mathrm{mg}(0.09 \mathrm{mmol})$ of $\mathbf{5 c}$ were added with $1 \mathrm{~mL}$ of tert-butanol. The mixture was heated at reflux $\left(100^{\circ} \mathrm{C}\right)$ for $30 \mathrm{~h}$. After $23 \mathrm{~h}$ additional sodium tert-butoxide $(85 \mathrm{mg}, 0.84 \mathrm{mmol})$ and another $10 \mathrm{mg}$ ( $0.05 \mathrm{mmol})$ of 2-chloro-5-hydrazinylbenzoic acid hydrochloride were added. The reaction was quenched with water and EtOAc. The $\mathrm{pH}$ was set to 3 with $0.5-\mathrm{M} \mathrm{HCl}$. The combined organic layers were washed with brine, dried over sodium sulfate, filtered and concentrated. The crude was dissolved in 2-3 mL EtOAc and kept at $0^{\circ} \mathrm{C}$ for $72 \mathrm{~h}$. Orange precipitation formed, which was filtered and resulted in a product weight of $14.3 \mathrm{mg}$ (31\% yield). MS (ESI) calculated for $\mathrm{C}_{22} \mathrm{H}_{14} \mathrm{ClF}_{3} \mathrm{~N}_{5} \mathrm{O}_{3}{ }^{+}: 488.1 ; m / z$ found $488.1[\mathrm{M}+\mathrm{H}]^{+}$; rt $13.64 \mathrm{~min}, 95 \%$. 
Ethyl-3-methoxy-3-(3-(trifluoromethyl)phenyl)acrylate (4). $5 \mathrm{~mL} \quad$ (28 mmol) ethyl 3(trifluoro-methyl)benzoate were dissolved in $200 \mathrm{~mL}$ EtOAc. $1.13 \mathrm{mg}$ (28 mmol) sodium hydride was added under stirring and heated to $40^{\circ} \mathrm{C}$ for $5 \mathrm{~min}$, before another $1.13 \mathrm{mg}$ ( $\left.28 \mathrm{mmol}\right)$ sodium hydride was added and the reaction mixture was heated under reflux $\left(90^{\circ} \mathrm{C}\right)$ for $18 \mathrm{~h}$. The reaction was cooled to rt and DCM/water was added. Extraction was performed and the combined organic layers were washed with brine, dried over sodium sulfate, filtered and concentrated. The crude was further dried with benzene under reduced pressure. In a second step, the crude intermediate was dissolved in $100 \mathrm{~mL}$ 4:1 MeCN:MeOH and $28 \mathrm{~mL}$ (56 mmol) 2-M (diazomethyl)trimethylsilane in hexane was added. The reaction was stirred for $36 \mathrm{~h}$ at rt, before it was quenched with $8 \mathrm{~mL}$ aqueous 1-M HCl and extraction was performed with EtOAc. The combined organic layers were washed with brine, dried over sodium sulfate, filtered and concentrated, which resulted in $9.63 \mathrm{~g}$ crude. Flash chromatography was performed with 95:5 hexane:EtOAc, resulting in a product weight of $3.74 \mathrm{~g}$ (48\% yield). ${ }^{1} \mathrm{H}$ NMR (400 MHz, Chloroform-d) $\delta 7.81$ (s, 1H), 7.74 (d, $J=7.5$ $\mathrm{Hz}, 1 \mathrm{H}), 7.68(\mathrm{~d}, J=7.5 \mathrm{~Hz}, 1 \mathrm{H}), 7.53(\mathrm{t}, J=7.5 \mathrm{~Hz}, 1 \mathrm{H}), 5.63(\mathrm{~s}, 1 \mathrm{H}), 4.22(\mathrm{q}, J=7.1 \mathrm{~Hz}, 2 \mathrm{H})$, $3.90(\mathrm{~s}, 3 \mathrm{H}), 1.31(\mathrm{t}, J=7.1 \mathrm{~Hz}, 4 \mathrm{H}) .{ }^{19} \mathrm{~F}$ NMR (376 MHz, Chloroform- $d$ ) $\delta-62.80$. HR-MS (ESI) calculated for $\mathrm{C}_{13} \mathrm{H}_{14} \mathrm{~F}_{3} \mathrm{O}_{3}{ }^{+}: 275.0890 ; \mathrm{m} / z$ found was $275.0895[\mathrm{M}+\mathrm{H}]^{+}$.

Methyl 4-hydroxylcinnoline-3-carboxylate (5a). To a mixture of $6 \mathrm{~mL}$ (84 mmol) thionylchloride and $10 \mathrm{~mL}$ chloroform, $4 \mathrm{~g} \quad(19 \mathrm{mmol})$ of compound 2-(2phenylhydrazono)malonic acid was added. The reaction mixture was stirred at $80^{\circ} \mathrm{C}$ for two hours under nitrogen atmosphere. The solvents were removed under vacuum and the brown residue was re-dissolved in dichloroethane and dried again. The resulting acid chloride was dissolved in $10 \mathrm{~mL}$ 
dichloroethane, then $1.2 \mathrm{~mL} \mathrm{TiCl}_{4}$ were added and the dark brown solution was stirred at $110^{\circ} \mathrm{C}$ for 4 hours under nitrogen. The reaction mixture was cooled to $10^{\circ} \mathrm{C}, 20 \mathrm{~mL}$ methanol were added slowly and the resulting red-brown solution was stirred at $60^{\circ} \mathrm{C}$ for $30 \mathrm{~min}$. The solvents were removed under reduced pressure and the residues were crystalized from $10 \mathrm{~mL}$ acetonitrile to yield $0.6 \mathrm{~g}$ of compound 5a (15\% yield). ${ }^{1} \mathrm{H}$ NMR (400 MHz, DMSO- $\left.d 6\right) \delta 13.94(\mathrm{~s}, 1 \mathrm{H}), 8.10(\mathrm{~d}, J=$ $8.2 \mathrm{~Hz}, 1 \mathrm{H}), 7.84(\mathrm{t}, J=7.7 \mathrm{~Hz}, 1 \mathrm{H}), 7.68(\mathrm{~d}, J=8.2 \mathrm{~Hz}, 1 \mathrm{H}), 7.52(\mathrm{t}, J=7.7 \mathrm{~Hz}, 1 \mathrm{H}), 3.83(\mathrm{~s}$, 3H). MS (ESI) calculated for $\mathrm{C}_{10} \mathrm{H}_{9} \mathrm{~N}_{2} \mathrm{O}_{3}{ }^{+}: 205.1 ; m / z$ found was $204.7[\mathrm{M}+\mathrm{H}]^{+}$.

Methyl 4-hydroxy-8-fluorocinnoline-3-carboxylate (5b). Compound $\mathbf{5 b}$ was synthesized in an analogous way to the procedure for compound 5a, but with 2-(2-(2fluorophenyl)hydrazono)malonic acid. ${ }^{1} \mathrm{H}$ NMR (400 MHz, DMSO-d6) $\delta 14.19$ (s, 1H), 7.90 (d, $J$ $=8.2 \mathrm{~Hz}, 1 \mathrm{H}), 7.77(\mathrm{ddd}, J=11.2,8.0,1.2 \mathrm{~Hz}, 1 \mathrm{H}), 7.49(\mathrm{td}, J=8.1,4.8 \mathrm{~Hz}, 1 \mathrm{H}), 3.85(\mathrm{~s}, 3 \mathrm{H})$. MS (ESI) calculated for $\mathrm{C}_{10} \mathrm{H}_{8} \mathrm{FN}_{2} \mathrm{O}_{3}{ }^{+}: 223.0 ; \mathrm{m} / \mathrm{z}$ found was $222.9[\mathrm{M}+\mathrm{H}]^{+}$.

\section{Ethyl 4-chloro-1-methyl-6-(3-(trifluoromethyl)phenyl)-1H-pyrazolo[3,4-b]pyridine-5-car-}

boxylate (5c). This intermediate was synthesised from 4 following the same experimental procedure like the synthesis of 5e and ethyl 5-amino-1-methyl-1H-pyrazole-4-carboxylate, resulting in a product weight of $830 \mathrm{mg}\left(60 \%\right.$ yield). ${ }^{1} \mathrm{H}$ NMR (400 MHz, Chloroform-d) $\delta 8.18$ (s, 1H), $7.96(\mathrm{~s}, 1 \mathrm{H}), 7.88(\mathrm{~d}, J=7.8 \mathrm{~Hz}, 1 \mathrm{H}), 7.73(\mathrm{~d}, J=7.8 \mathrm{~Hz}, 1 \mathrm{H}), 7.60(\mathrm{t}, J=7.8 \mathrm{~Hz}, 1 \mathrm{H})$, $4.22(\mathrm{q}, J=7.1 \mathrm{~Hz}, 2 \mathrm{H}), 4.20(\mathrm{~s}, 3 \mathrm{H}), 1.12(\mathrm{t}, J=7.1 \mathrm{~Hz}, 3 \mathrm{H})$. MS (ESI) calculated for $\mathrm{C}_{17} \mathrm{H}_{14} \mathrm{ClF}_{3} \mathrm{~N}_{3} \mathrm{O}_{2}{ }^{+}: 384.1 ; \mathrm{m} / z$ found was $384.2[\mathrm{M}+\mathrm{H}]^{+}$. 
Ethyl 4-chloro-2-(3-(trifluoromethyl)phenyl)quinoline-3-carboxylate (5d). This intermediate was synthesised from 4 following the same experimental procedure like the synthesis of $\mathbf{5 e}$ and ethyl-2-aminobenzoate, resulting in a product weight of $418 \mathrm{mg}(61 \%$ yield $) .{ }^{1} \mathrm{H}$ NMR $(400 \mathrm{MHz}$, Chloroform-d) $\delta 8.32(\mathrm{~d}, J=8.4 \mathrm{~Hz}, 1 \mathrm{H}), 8.19(\mathrm{~d}, J=8.4 \mathrm{~Hz}, 1 \mathrm{H}), 8.03(\mathrm{~s}, 1 \mathrm{H}), 7.95(\mathrm{~d}, J=7.8$ $\mathrm{Hz}, 1 \mathrm{H}), 7.86(\mathrm{t}, J=8.4 \mathrm{~Hz}, 1 \mathrm{H}), 7.77-7.69(\mathrm{~m}, 2 \mathrm{H}), 7.62$ (t, $J=7.8 \mathrm{~Hz}, 1 \mathrm{H}), 4.29(\mathrm{q}, J=7.2$ $\mathrm{Hz}, 2 \mathrm{H}), 1.18(\mathrm{t}, J=7.2 \mathrm{~Hz}, 3 \mathrm{H}) .{ }^{13} \mathrm{C} \mathrm{NMR}\left(101 \mathrm{MHz}, \mathrm{CDCl}_{3}\right) \delta 166.2,154.7,148.0,141.2,140.0$, $132.0,131.0,130.1,129.3,128.8,127.1,126.9,126.2,125.6,125.4,124.7,122.7,62.6,13.8 .{ }^{19} \mathrm{~F}$ NMR (376 MHz, Chloroform- $d$ ) $\delta$-62.68. HR-MS (ESI) was calculated for $\mathrm{C}_{19} \mathrm{H}_{13} \mathrm{ClF}_{3} \mathrm{NNaO}_{2}{ }^{+}$: $380.0660 ; \mathrm{m} / \mathrm{z}$ found was $380.0663[\mathrm{M}+\mathrm{H}]^{+}$.

Ethyl 4-chloro-8-fluoro-2-(3-(trifluoromethyl)phenyl)quinoline-3-carboxylate (5e). $740 \mathrm{mg}$ (4.4 mmol) of methyl 2-amino-3-fluorobenzoate were dissolved in $8 \mathrm{~mL}$ THF, before $193 \mathrm{mg}$ (4.8 mmol) sodium hydride was added and the mixture was stirred at room temperature. After $30 \mathrm{~min}, 1.20 \mathrm{~g}$ ( $4.4 \mathrm{mmol})$ of 4 with $1.7 \mathrm{~mL}$ THF was transferred to the mixture. The reaction was run under reflux for $16 \mathrm{~h}$, before it was cooled to room temperature and quenched with water. The $\mathrm{pH}$ was set to 5 with aqueous $\mathrm{HCl}$. Extraction was performed with EtOAc and the combined organic fractions were dried, filtered and concentrated, which resulted in a crude weight of $1.86 \mathrm{~g}$. The crude was dissolved in $19 \mathrm{~mL}$ phosphorus oxychloride and stirred at reflux for $2 \mathrm{~h}$. After cooling to room temperature, it was concentrated under reduced pressure. The residues were dissolved in EtOAc, cooled to $0^{\circ} \mathrm{C}$ and neutralised with aqueous $5 \% \mathrm{NaHCO}_{3}$. Extraction was performed with EtOAc and the collected organic layers were dried over sodium sulfate and concentrated, resulting in a crude weight of $1.81 \mathrm{~g}$. Flash chromatography (9:1 Hexane:EtOAc) was performed, giving a product weight of $955 \mathrm{mg}$ (55\% yield). ${ }^{1} \mathrm{H}$ NMR (400 MHz, Chloroform- 
d) $\delta 8.12(\mathrm{~d}, J=8.5 \mathrm{~Hz}, 1 \mathrm{H}), 8.02(\mathrm{~s}, 1 \mathrm{H}), 7.98(\mathrm{~d}, J=7.7 \mathrm{~Hz}, 1 \mathrm{H}), 7.75(\mathrm{~d}, J=7.7 \mathrm{~Hz}, 1 \mathrm{H}), 7.72$ $-7.54(\mathrm{~m}, 3 \mathrm{H}), 4.30(\mathrm{q}, J=7.1 \mathrm{~Hz}, 1 \mathrm{H}), 3.84(\mathrm{~s}, 2 \mathrm{H}), 1.19(\mathrm{t}, J=7.1 \mathrm{~Hz}, 1 \mathrm{H}) .{ }^{13} \mathrm{C}$ NMR $(101$ $\left.\mathrm{MHz}, \mathrm{CDCl}_{3}\right) \delta 165.9,159.5,156.9,154.8,139.7,132.2,129.5,128.6,128.5,128.1,126.4,126.3$, 125.6, 125.4, 122.7, 120.5, 116.2, 62.8, 13.8. ${ }^{19} \mathrm{~F}$ NMR (376 MHz, Chloroform- $d$ ) $\delta-62.66$, 122.57. HR-MS (ESI) calculated for $\mathrm{C}_{19} \mathrm{H}_{13} \mathrm{ClF}_{4} \mathrm{NO}_{2}{ }^{+}: 398.0565 ; \mathrm{m} / z$ found was 398.0565 $[\mathrm{M}+\mathrm{H}]^{+}$.

4-(3-oxo-1,3-dihydro-2H-pyrazolo[4,3-c]cinnolin-2-yl)benzoic acid (6a). $0.5 \mathrm{~g}$ (2.4 mmol) of compound 5a were added in $2 \mathrm{~mL}(27 \mathrm{mmol})$ thionyl chloride and the reaction mixture was stirred at $80^{\circ} \mathrm{C}$ for $1 \mathrm{~h}$. The excess of thionyl chloride was removed under vacuum. The residue was dissolved in toluene and the solvent was removed under vacuum to remove the traces of thionyl chloride. Then $0.73 \mathrm{~g}(4.8 \mathrm{mmol})$ 4-hydrazinylbenzoic acid and $7 \mathrm{~mL}$ ethanol were added and the reaction mixture was stirred at $70^{\circ} \mathrm{C}$ for $1 \mathrm{~h}$. The resulting precipitates were collected and washed with methanol:37\% aqueous $\mathrm{HCl}$ mixture $(9: 1,10 \mathrm{~mL})$. The crude product was washed additionally 3 times with water, methanol, and methylene chloride and dried to yield $0.57 \mathrm{~g}$ of compound 6a (78\% yield). ${ }^{1} \mathrm{H}$ NMR (400 MHz, DMSO- $\left.d_{6}\right) \delta 14.62(\mathrm{~s}, 1 \mathrm{H}), 12.84(\mathrm{~s}, 1 \mathrm{H}), 8.33(\mathrm{~d}$, $J=8.9 \mathrm{~Hz}, 2 \mathrm{H}), 8.21(\mathrm{~d}, J=7.8 \mathrm{~Hz}, 1 \mathrm{H}), 8.06(\mathrm{~d}, J=8.9 \mathrm{~Hz}, 2 \mathrm{H}), 7.86-7.78(\mathrm{~m}, 2 \mathrm{H}), 7.73-$ $7.66(\mathrm{~m}, 1 \mathrm{H}) . \mathrm{MS}(\mathrm{ESI})$ calculated for $\mathrm{C}_{16} \mathrm{H}_{11} \mathrm{~N}_{4} \mathrm{O}_{3}{ }^{+}: 307.1 ; \mathrm{m} / \mathrm{z}$ found was $306.7[\mathrm{M}+\mathrm{H}]^{+}$; rt $10.78 \mathrm{~min},>99 \%$.

4-(6-fluoro-3-oxo-1,3-dihydro-2H-pyrazolo[4,3-c]cinnolin-2-yl)benzoic acid (6b). The structure was synthesised in an analogous way to the procedure of compound $\mathbf{6 a}$ with compound 5b as starting material. ${ }^{1} \mathrm{H}$ NMR $\left(400 \mathrm{MHz}, \mathrm{DMSO}-d_{6}\right) \delta 14.71(\mathrm{~s}, 1 \mathrm{H}), 12.87(\mathrm{~s}, 1 \mathrm{H}), 8.26(\mathrm{~d}, J$ 
$=8.9 \mathrm{~Hz}, 2 \mathrm{H}), 8.02(\mathrm{~d}, J=8.9 \mathrm{~Hz}, 2 \mathrm{H}), 7.96(\mathrm{~d}, J=7.8 \mathrm{~Hz}, 1 \mathrm{H}), 7.73-7.58(\mathrm{~m}, 2 \mathrm{H})$. MS (ESI) calculated for $\mathrm{C}_{16} \mathrm{H}_{11} \mathrm{FN}_{4} \mathrm{O}_{3}{ }^{+}: 325.1 ; m / z$ found was $324.7[\mathrm{M}+\mathrm{H}]^{+}$.

\section{4-(6-methyl-3-oxo-4-(3-(trifluoromethyl)phenyl)-3,6-dihydrodipyrazolo[3,4-b:3',4'-}

d]pyridin-2(1H)-yl)benzoic acid (6c). This intermediate was synthesised from $\mathbf{5 c}$ following the experimental procedure like the synthesis of $\mathbf{6 e}$, resulting in a product weight of $825 \mathrm{mg}$ (85\% yield). ${ }^{1} \mathrm{H}$ NMR (400 MHz, Acetone- $\left.d_{6}\right) \delta 12.24(\mathrm{~s}, 1 \mathrm{H}), 8.45(\mathrm{~s}, 1 \mathrm{H}), 8.39$ (d, $\left.J=7.8 \mathrm{~Hz}, 1 \mathrm{H}\right)$, $8.22(\mathrm{~s}, 1 \mathrm{H}), 8.12(\mathrm{~s}, 4 \mathrm{H}), 7.87(\mathrm{~d}, J=7.8 \mathrm{~Hz}, 1 \mathrm{H}), 7.76(\mathrm{t}, J=7.8 \mathrm{~Hz}, 1 \mathrm{H}), 4.16(\mathrm{~s}, 3 \mathrm{H}) .{ }^{19} \mathrm{~F}$ NMR (376 MHz, Acetone- $\left.d_{6}\right) \delta-62.88$. HR-MS (ESI) calculated for $\mathrm{C}_{22} \mathrm{H}_{15} \mathrm{~F}_{3} \mathrm{~N}_{5} \mathrm{O}_{3}{ }^{+}: 454.1122 ; \mathrm{m} / z$ found was $454.1128[\mathrm{M}+\mathrm{H}]^{+}$; rt $13.31 \mathrm{~min},>99 \%$.

\section{4-(3-oxo-4-(3-(trifluoromethyl)phenyl)-1,3-dihydro-2H-pyrazolo[4,3-c]quinolin-2-}

yl)benzoic acid (6d). This intermediate was synthesised from $\mathbf{5 d}$ following the same experimental procedure like the synthesis of $\mathbf{6 e}$, resulting in a product weight of $120 \mathrm{mg}\left(68 \%\right.$ yield). ${ }^{1} \mathrm{H}$ NMR $\left(400 \mathrm{MHz}, \mathrm{DMSO}-d_{6}\right) \delta 12.72(\mathrm{~s}, 1 \mathrm{H}), 8.39-8.32(\mathrm{~m}, 3 \mathrm{H}), 8.30(\mathrm{~d}, J=7.6 \mathrm{~Hz}, 1 \mathrm{H}), 8.25(\mathrm{~d}, J=$ $7.8 \mathrm{~Hz}, 1 \mathrm{H}), 8.05(\mathrm{~d}, J=7.8 \mathrm{~Hz}, 1 \mathrm{H}), 8.01(\mathrm{~d}, J=8.9 \mathrm{~Hz}, 2 \mathrm{H}), 7.90-7.84(\mathrm{~m}, 2 \mathrm{H}), 7.73(\mathrm{t}, J=$ $7.6 \mathrm{~Hz}, 1 \mathrm{H}), 7.60(\mathrm{t}, J=7.6 \mathrm{~Hz}, 1 \mathrm{H}) .{ }^{13} \mathrm{C} \mathrm{NMR}\left(101 \mathrm{MHz}, \mathrm{DMSO}-d_{6}\right) \delta 167.5,162.0,151.3$, $144.7,143.9,136.6,134.7,131.0,130.9,130.7,129.7,128.5,127.4,127.1,126.1,125.8,123.1$, 122.4, 120.3, $118.7118 .2,102.6 .{ }^{19} \mathrm{~F}$ NMR $\left(376 \mathrm{MHz}, \mathrm{DMSO}-d_{6}\right) \delta-60.96 . \mathrm{MS}$ (ESI) calculated for $\mathrm{C}_{24} \mathrm{H}_{15} \mathrm{~F}_{3} \mathrm{~N}_{3} \mathrm{O}_{3}{ }^{+}: 450.1 ; m / z$ found was $450.1[\mathrm{M}+\mathrm{H}]^{+}$; rt 13.35 min, 92\%. 


\section{4-(6-fluoro-3-oxo-4-(3-(trifluoromethyl)phenyl)-1,3-dihydro-2H-pyrazolo[4,3-c]quinolin-2-}

yl)benzoic acid (6e). $429 \mathrm{mg}$ (2.82 mmol) of 4-hydrazinylbenzoic acid were dissolved in $4.7 \mathrm{~mL}$ ethylene glycol, $279 \mathrm{mg}(2.82 \mathrm{mmol})$ sodium tert-butoxide were added and stirred at $75^{\circ} \mathrm{C}$ for $1 \mathrm{~h}$. After cooling, $374 \mathrm{mg}(0.94 \mathrm{mmol})$ of $\mathbf{5 e}$ dissolved in $2.0 \mathrm{~mL}$ THF were added and the reaction mixture was heated to $100^{\circ} \mathrm{C}$. After $16 \mathrm{~h}$, another $100 \mathrm{mg}$ of sodium tert-butoxide was added and stirred at $100^{\circ} \mathrm{C}$ for another $3 \mathrm{~h}$. The reaction was quenched with $\mathrm{H}_{2} \mathrm{O}$ and EtOAc. The crude solution was acidified to $\mathrm{pH} 3$ using 1-M HCl and extracted with EtOAc. The organic layers were dried with sodium sulfate and concentrated, giving $54.4 \mathrm{mg}$ crude. For purification, trituration was performed as described in the synthesis for $\mathbf{7 g}$. In short, the crude was dissolved in aceton, few 1-M HCl was added and the solution was concentrated at $100 \mathrm{mbar}$ at $40^{\circ} \mathrm{C}$ until precipitate formed. The suspension was stored in the fridge for $1 \mathrm{~h}$. Filtration, washing with 1-M $\mathrm{HCl}$ and cold $\mathrm{H}_{2} \mathrm{O}$, and subsequent drying, resulted in a product weight of $288 \mathrm{mg}$ (66\% yield). ${ }^{1} \mathrm{H}$ NMR (400 MHz, DMSO-d6) $\delta 12.79(\mathrm{~s}, 1 \mathrm{H}), 12.58(\mathrm{~s}, 1 \mathrm{H}), 8.30(\mathrm{~d}, J=8.9 \mathrm{~Hz}, 2 \mathrm{H}), 8.24(\mathrm{~s}, 1 \mathrm{H}), 8.17$ $(\mathrm{d}, J=7.8 \mathrm{~Hz}, 1 \mathrm{H}), 8.08(\mathrm{~d}, J=7.4 \mathrm{~Hz}, 1 \mathrm{H}), 8.04-7.95(\mathrm{~m}, 3 \mathrm{H}), 7.81(\mathrm{t}, J=7.8 \mathrm{~Hz}, 1 \mathrm{H}), 7.71-$ $7.43(\mathrm{~m}, 2 \mathrm{H}) .{ }^{13} \mathrm{C}$ NMR (101 MHz, DMSO-d6) $\delta 167.0,161.3,153.7,151.9,151.2,143.5,143.3$, 134.6, 130.3, 128.8, 128.5, 128.2, 127.7, $127.2,126.9$ (d, $J=7.6 \mathrm{~Hz}), 125.7,125.5,122.8,120.4$, 117.7, $115.8(\mathrm{~d}, J=17.1 \mathrm{~Hz}), 103.1 .{ }^{19} \mathrm{~F}$ NMR (376 MHz, DMSO-d6) $\delta-60.92,-124.46 . \mathrm{HR}-\mathrm{MS}$ (ESI) calculated for $\mathrm{C}_{24} \mathrm{H}_{14} \mathrm{~F}_{4} \mathrm{~N}_{3} \mathrm{O}_{3}{ }^{+}: 468.0966 ; \mathrm{m} / \mathrm{z}$ found was $468.0966[\mathrm{M}+\mathrm{H}]^{+}$.

\section{$\mathrm{N}$-(1-methylpiperidin-4-yl)-4-(3-oxo-1,3-dihydro-2 $H$-pyrazolo[4,3-c]cinnolin-2-}

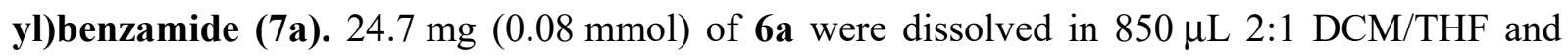
$240 \mu \mathrm{L}(3.3 \mathrm{mmol})$ thionylchloride was added. The mixture was stirred at reflux for $3 \mathrm{~h}$. The reaction was cooled down and solvents were evaporated under reduced pressure. Benzene was 
added two times to remove solvent residues, resulting in a crude weight of $32.1 \mathrm{mg}$. This crude was then resuspended in $200 \mu \mathrm{L}$ DMF. $12.7 \mu \mathrm{L}(0.10 \mathrm{mmol})$ 1-methylpiperidin-4-amine and $22.8 \mu \mathrm{L}(0.16 \mathrm{mmol})$ triethylamine were mixed with $210 \mu \mathrm{L}$ DMF in a separate flask and then added to the reaction. After 20 hours, the reaction was stopped by adding aqueous $\mathrm{HCl}$ solution and EtOAc, which led to the formation of precipitates. The precipitates were washed with aqueous $\mathrm{HCl}$ solution and cold water. The precipitates were dissolved with ethanol/water and concentrated to half the volume and stored in the fridge overnight. Orange precipitates formed and were filtered and washed. The precipitates were treated with toluene and dried under high-vacuum to give a final product weight of $6.4 \mathrm{mg}$ (19\% yield). ${ }^{1} \mathrm{H}$ NMR (400 MHz, DMSO-d6) $\delta 8.35(\mathrm{~d}, J=8.9 \mathrm{~Hz}$, 2H), $8.33-8.29(\mathrm{~m}, 1 \mathrm{H}), 8.21(\mathrm{~d}, J=8.0,1 \mathrm{H}), 7.97(\mathrm{~d}, J=8.9 \mathrm{~Hz}, 2 \mathrm{H}), 7.90(\mathrm{~d}, J=8.0 \mathrm{~Hz}, 1 \mathrm{H})$, $7.78(\mathrm{t}, J=7.7 \mathrm{~Hz}, 1 \mathrm{H}), 7.66(\mathrm{t}, J=7.7 \mathrm{~Hz}, 1 \mathrm{H}), 3.96-3.83(\mathrm{~m}, 1 \mathrm{H}), 3.14-3.03(\mathrm{~m}, 2 \mathrm{H}), 2.57-$ $2.51(\mathrm{~m}, 2 \mathrm{H}), 2.45(\mathrm{~s}, 3 \mathrm{H}), 1.94-1.86(\mathrm{~m}, 2 \mathrm{H}), 1.79-1.66(\mathrm{~m}, 2 \mathrm{H})$. HR-MS (ESI) calculated for $\mathrm{C}_{22} \mathrm{H}_{23} \mathrm{~N}_{6} \mathrm{O}_{2}{ }^{+}: 403.1877 ; m / z$ found was $403.1875[\mathrm{M}+\mathrm{H}]^{+} ;$rt $9.32 \mathrm{~min}, 97 \%$.

\section{4-(6-fluoro-3-oxo-1,3-dihydro-2H-pyrazolo[4,3-c] cinnolin-2-yl)- $N$-(3-(1-}

hydroxyethyl)phenyl)benzamide (7b). This structure was synthesised from $20 \mathrm{mg}$ of $\mathbf{6 b}$ following the same experimental procedure like the synthesis of $\mathbf{7 c}$, resulting in a product weight of $11 \mathrm{mg}$ (40\% yield). ${ }^{1} \mathrm{H}$ NMR (400 MHz, DMSO- $\left.d_{6}\right) \delta 10.23(\mathrm{~s}, 1 \mathrm{H}), 8.34(\mathrm{~d}, J=8.9 \mathrm{~Hz}, 2 \mathrm{H})$, $8.13(\mathrm{~d}, J=8.9 \mathrm{~Hz}, 2 \mathrm{H}), 8.05(\mathrm{~d}, J=7.6 \mathrm{~Hz}, 1 \mathrm{H}), 7.77(\mathrm{~s}, 1 \mathrm{H}), 7.77(\mathrm{~s}, 1 \mathrm{H}), 7.76-7.64(\mathrm{~m}, 3 \mathrm{H})$, $7.29(\mathrm{t}, J=7.8 \mathrm{~Hz}, 1 \mathrm{H}), 7.08(\mathrm{~d}, J=7.8 \mathrm{~Hz}, 1 \mathrm{H}), 5.19(\mathrm{~s}, 1 \mathrm{H}), 4.72(\mathrm{q}, J=6.5 \mathrm{~Hz}, 1 \mathrm{H}), 1.34(\mathrm{~d}$, $J=6.5 \mathrm{~Hz}, 3 \mathrm{H}) .{ }^{19} \mathrm{~F}$ NMR $(376 \mathrm{MHz}, \mathrm{DMSO}-d 6) \delta-125.47$. HR-MS (MALDI/ESI) calculated for $\mathrm{C}_{24} \mathrm{H}_{18} \mathrm{FN}_{5} \mathrm{NaO}_{3}{ }^{+}: 466.1286 ; \mathrm{m} / z$ found was $466.1282[\mathrm{M}+\mathrm{Na}]^{+}$; rt $11.64 \mathrm{~min}, 98 \%$. 


\section{$N$-(3-(1-hydroxyethyl)phenyl)-4-(3-oxo-1,3-dihydro-2H-pyrazolo[4,3-c]cinnolin-2-}

yl)benzamide (7c). $15 \mathrm{mg}(0.05 \mathrm{mmol})$ of 6 a were dissolved in $600 \mu \mathrm{L} 2: 1 \mathrm{DMF} / \mathrm{THF}$ and $21 \mathrm{mg}$ (0.15 mmol) of 1-(3-aminophenyl)ethan-1-ol as well as $24 \mathrm{mg}$ (0.12 mmol) 1-ethyl-3(3-dimethylaminopropyl)carbo-diimid hydrochloride (EDC $\cdot \mathrm{HCl})$ were added. Afterwards, $16 \mu \mathrm{L}$ (0.09 mmol) DIPEA were added and the reaction was stirred for $16 \mathrm{~h}$ at room temperature, before the reaction was quenched by the addition of EtOAc and aqueous $0.25-\mathrm{M} \mathrm{HCl}$. The organic layers were dried over sodium sulfate and concentrated, resulting in a crude weight of $35.1 \mathrm{mg}$. Flash chromatography $\left(9: 1 \mathrm{EtOAc} / \mathrm{EtOH}\right.$, saturated with $\left.\mathrm{NH}_{4} \mathrm{HCO}_{3}\right)$ was used for purification, which resulted in a product weight of $2.8 \mathrm{mg}\left(13 \%\right.$ yield). ${ }^{1} \mathrm{H}$ NMR $(400 \mathrm{MHz}$, Acetone-d6) $\delta 9.49$ (s, $1 \mathrm{H}), 8.45(\mathrm{~d}, J=8.9 \mathrm{~Hz}, 2 \mathrm{H}), 8.38(\mathrm{~s}, 1 \mathrm{H}), 8.32(\mathrm{~d}, J=7.8 \mathrm{~Hz}, 1 \mathrm{H}), 8.21(\mathrm{~d}, J=7.8 \mathrm{~Hz}, 1 \mathrm{H}), 8.12$ $(\mathrm{d}, J=8.9 \mathrm{~Hz}, 2 \mathrm{H}), 8.01(\mathrm{~d}, J=7.8 \mathrm{~Hz}, 1 \mathrm{H}), 7.92-7.81(\mathrm{~m}, 2 \mathrm{H}), 7.79(\mathrm{~d}, J=7.7 \mathrm{~Hz}, 1 \mathrm{H}), 7.63$ $-7.54(\mathrm{~m}, 2 \mathrm{H}), 7.29$ (t, $J=7.7 \mathrm{~Hz}, 1 \mathrm{H}), 7.13(\mathrm{~d}, J=7.7 \mathrm{~Hz}, 1 \mathrm{H}), 4.85$ (q, $J=6.4 \mathrm{~Hz}, 1 \mathrm{H}), 4.17$ $(\mathrm{d}, J=4.1 \mathrm{~Hz}, 1 \mathrm{H}), 1.42(\mathrm{~d}, J=6.4 \mathrm{~Hz}, 3 \mathrm{H})$. HR-MS (ESI) calculated for $\mathrm{C}_{24} \mathrm{H}_{19} \mathrm{~N}_{5} \mathrm{NaO}_{3}{ }^{+}$: 448.1380; $\mathrm{m} / \mathrm{z}$ found was $448.1386[\mathrm{M}+\mathrm{Na}]^{+}$; rt $11.53 \mathrm{~min}, 95 \%$.

\section{4-(6-methyl-3-oxo-4-(3-(trifluoromethyl)phenyl)-3,6-dihydrodipyrazolo[3,4-b:3',4'-}

d]pyridin-2(1H)-yl)-N-(1-methylpiperidin-4-yl)benzamide (7d). This structure was synthesised from $20 \mathrm{mg}$ of $\mathbf{6 c}$ following the same experimental procedure like the synthesis of $\mathbf{7 c}$, resulting in a product weight of $16 \mathrm{mg}$ (66\% yield). ${ }^{1} \mathrm{H}$ NMR (400 MHz, DMSO- $\left.d_{6}\right) \delta 10.62(\mathrm{~s}, 1 \mathrm{H}), 8.59(\mathrm{~d}$, $J=7.5 \mathrm{~Hz}, 1 \mathrm{H}), 8.35-8.24(\mathrm{~m}, 3 \mathrm{H}), 8.12-7.98(\mathrm{~m}, 4 \mathrm{H}), 7.89(\mathrm{~d}, J=7.8 \mathrm{~Hz}, 1 \mathrm{H}), 7.76(\mathrm{t}, J=$ $7.8 \mathrm{~Hz}, 1 \mathrm{H}), 4.11(\mathrm{~s}, 3 \mathrm{H}), 4.08-3.97(\mathrm{~m}, 1 \mathrm{H}), 3.46-3.42(\mathrm{~m}, 3 \mathrm{H}), 3.15-3.01(\mathrm{~m}, 2 \mathrm{H}), 2.79-$ $2.68(\mathrm{~m}, 2 \mathrm{H}), 2.07-1.90(\mathrm{~m}, 4 \mathrm{H}) .{ }^{19} \mathrm{~F}$ NMR $\left(376 \mathrm{MHz}, \mathrm{DMSO}-d_{6}\right) \delta-60.88 . \mathrm{HR}-\mathrm{MS}$ (ESI) calculated for $\mathrm{C}_{28} \mathrm{H}_{27} \mathrm{~F}_{3} \mathrm{~N}_{7} \mathrm{O}_{2}{ }^{+}: 550.2173 ; \mathrm{m} / z$ found was $550.2167[\mathrm{M}+\mathrm{H}]^{+}$; rt $11.71 \mathrm{~min}, 97 \%$. 


\section{$\mathrm{N}$-(1-methylpiperidin-4-yl)-4-(3-oxo-4-(3-(trifluoromethyl)phenyl)-1,3-dihydro-2H-}

pyrazolo[4,3-c]quinolin-2-yl)benzamide (7e). This intermediate was synthesised from $\mathbf{6 d}$ following the same experimental procedure like the synthesis of $\mathbf{7 f}$, resulting in a product weight of $31 \mathrm{mg}\left(66 \%\right.$ yield). ${ }^{1} \mathrm{H}$ NMR (400 MHz, DMSO- $\left.d_{6}\right) \delta 8.40(\mathrm{~s}, 1 \mathrm{H}), 8.39-8.30(\mathrm{~m}, 3 \mathrm{H}), 8.28$ $(\mathrm{d}, J=8.2 \mathrm{~Hz}, 2 \mathrm{H}), 7.98(\mathrm{~d}, J=7.8 \mathrm{~Hz}, 2 \mathrm{H}), 7.93(\mathrm{~d}, J=8.9 \mathrm{~Hz}, 2 \mathrm{H}), 7.87-7.77(\mathrm{~m}, 2 \mathrm{H}), 7.66$ (t, $J=7.6 \mathrm{~Hz}, 1 \mathrm{H}), 7.53(\mathrm{t}, J=7.6 \mathrm{~Hz}, 1 \mathrm{H}), 3.94-3.81(\mathrm{~m}, 1 \mathrm{H}), 3.15-2.96(\mathrm{~m}, 2 \mathrm{H}), 2.49-2.33$ $(\mathrm{m}, 4 \mathrm{H}), 1.93-1.84(\mathrm{~m}, 2 \mathrm{H}), 1.76-1.63(\mathrm{~m}, 2 \mathrm{H}) .{ }^{13} \mathrm{C}$ NMR $\left(101 \mathrm{MHz}, \mathrm{DMSO}-d_{6}\right) \delta 165.3,161.3$, $152.1,145.0,143.7,142.7,134.2,129.7,129.1,128.9,128.7,128.0,127.1,126.7,125.9,125.5$, 124.2, 121.7, 119.6, 118.9, 117.5, 69.8, 53.7, 45.4, 44.5, 30.3, 29.0. ${ }^{19}$ F NMR (376 MHz, DMSOd6) $\delta$-60.87. HR-MS (ESI) calculated for $\mathrm{C}_{30} \mathrm{H}_{27} \mathrm{~F}_{3} \mathrm{~N}_{5} \mathrm{O}_{2}{ }^{+}: 546.2111 ; \mathrm{m} / z$ found was 546.2113 $[\mathrm{M}+\mathrm{H}]^{+} ;$rt $11.53 \mathrm{~min},>99 \%$.

\section{4-(6-fluoro-3-oxo-4-(3-(trifluoromethyl)phenyl)-1,3-dihydro-2H-pyrazolo[4,3-c]quinolin-2-}

yl)- $N$-(1-methylpiperidin-4-yl)benzamide (7f). $19.4 \mathrm{mg}(0.043 \mathrm{mmol})$ of 6 e were dissolved in $200 \mu \mathrm{L}$ DMF and stirred in a round-bottom flask. $18.6 \mathrm{mg}(0.047 \mathrm{mmol})$ HATU were added and the mixture was cooled to $0^{\circ} \mathrm{C}$. In a separate flask, $16.5 \mu \mathrm{L}(0.13 \mathrm{mmol}) 1$-methylpiperidin-4amine and $20 \mu \mathrm{L}(0.13 \mathrm{mmol}) \mathrm{DIPEA}$ were mixed with $90 \mu \mathrm{L}$ DMF and the solution was added dropwise into the reaction mixture at $0^{\circ} \mathrm{C}$ under vigorous stirring. The reaction was kept stirring for $35 \mathrm{~min}$, before it was quenched by adding 1-M $\mathrm{HCl}$ and transferred into an Erlenmeyer tube with ice and brine. This mixture was kept one hour in the fridge and formed precipitates. The suspension was filtered and the precipitates were washed with 1-M $\mathrm{HCl}$. Afterwards, the precipitates were dissolved with EtOH and run through a $0.45 \mu \mathrm{m}$ filter. The clear yellow solution 
was concentrated and dried under high-vacuum, which resulted in a product weight of $20.9 \mathrm{mg}$ (87\% yield). For crystal structure check Supplementary Figure S10. ${ }^{1} \mathrm{H}$ NMR (400 MHz, DMSOd6) $\delta 12.62(\mathrm{~s}, 1 \mathrm{H}), 10.52(\mathrm{~s}, 1 \mathrm{H}), 8.52(\mathrm{~d}, J=7.5 \mathrm{~Hz}, 1 \mathrm{H}), 8.26(\mathrm{~d}, J=8.9 \mathrm{~Hz}, 2 \mathrm{H}), 8.23(\mathrm{~s}, 1 \mathrm{H})$, $8.16(\mathrm{~d}, J=7.8 \mathrm{~Hz}, 1 \mathrm{H}), 8.13(\mathrm{~d}, J=7.6 \mathrm{~Hz}, 0 \mathrm{H}), 8.02(\mathrm{~d}, J=7.8 \mathrm{~Hz}, 1 \mathrm{H}), 7.97(\mathrm{~d}, J=8.9 \mathrm{~Hz}$, 2H), $7.83(\mathrm{t}, J=7.8 \mathrm{~Hz}, 1 \mathrm{H}), 7.70-7.55(\mathrm{~m}, 2 \mathrm{H}), 4.09-3.97(\mathrm{~m}, 1 \mathrm{H}), 3.50(\mathrm{~s}, 3 \mathrm{H}), 3.44-3.36$ $(\mathrm{m}, 2 \mathrm{H}), 3.16-2.99(\mathrm{~m}, 2 \mathrm{H}), 2.07-1.86(\mathrm{~m}, 4 \mathrm{H}) .{ }^{19} \mathrm{~F}$ NMR (376 MHz, DMSO-d6) $\delta-60.91$, 124.48. HR-MS (MALDI/ESI) calculated for $\mathrm{C}_{30} \mathrm{H}_{26} \mathrm{~F}_{4} \mathrm{~N}_{5} \mathrm{O}_{2}{ }^{+}: 564.2017 ; \mathrm{m} / z$ found was 564.2016 $[\mathrm{M}+\mathrm{H}]^{+} ;$rt $11.72 \min , 97 \%$.

\section{4-(6-fluoro-3-oxo-4-(3-(trifluoromethyl)phenyl)-1,3-dihydro-2H-pyrazolo[4,3-c]quinolin-2-}

yl)-N-(3-(1-hydroxyethyl)phenyl)benzamide (7g). $17.6 \mathrm{mg}(0.04 \mathrm{mmol})$ of $6 \mathbf{6 e}$ were dissolved in $190 \mu \mathrm{L}$ DMF and stirred in a round-bottom flask. $16.2 \mathrm{mg}(0.12 \mathrm{mmol}) 1$-(3-aminophenyl)ethan1-ol, $14.9 \mathrm{mg}(0.08 \mathrm{mmol}) \mathrm{EDC} \cdot \mathrm{HCl}$ and $12 \mu \mathrm{L}(0.07 \mathrm{mmol})$ DIPEA was added in this respective order. The reaction mixture was stirred at room temperature for $18 \mathrm{~h}$, before it was diluted with EtOAc. The organic layers were partitioned with $0.4-\mathrm{M} \mathrm{HCl}$, dried and concentrated. The crude

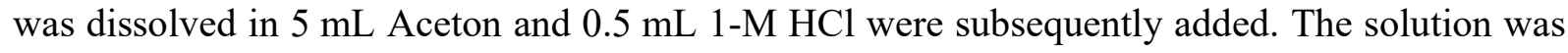
concentrated at $100 \mathrm{mbar}$ at $40^{\circ} \mathrm{C}$ until red-orange precipitate formed and was stored in the fridge for $1 \mathrm{~h}$. Afterwards the suspension was filtered and the precipitates were washed with 1-M $\mathrm{HCl}$ and cold $\mathrm{H}_{2} \mathrm{O}$. The precipitates were dissolved with 9:1 EtOAc:EtOH. The solution was concentrated and dried under high-vacuum, which resulted in a product weight of $5.5 \mathrm{mg}(25 \%$ yield). ${ }^{1} \mathrm{H}$ NMR (400 MHz, Acetone- $\left.d_{6}\right) \delta 9.49(\mathrm{~s}, 1 \mathrm{H}), 8.45(\mathrm{~d}, J=9.0 \mathrm{~Hz}, 2 \mathrm{H}), 8.38(\mathrm{~s}, 1 \mathrm{H}), 8.32$ $(\mathrm{d}, J=7.9 \mathrm{~Hz}, 1 \mathrm{H}), 8.21(\mathrm{dt}, J=7.8,1.3 \mathrm{~Hz}, 1 \mathrm{H}), 8.12(\mathrm{~d}, J=9.0 \mathrm{~Hz}, 2 \mathrm{H}), 8.01(\mathrm{~d}, J=8.0 \mathrm{~Hz}$, 1H), $7.88-7.77(\mathrm{~m}, 3 \mathrm{H}), 7.63-7.54(\mathrm{~m}, 2 \mathrm{H}), 7.29(\mathrm{t}, J=7.8 \mathrm{~Hz}, 1 \mathrm{H}), 7.13(\mathrm{~d}, J=7.8 \mathrm{~Hz}, 1 \mathrm{H})$, 
$4.85(\mathrm{q}, J=6.1 \mathrm{~Hz}, 1 \mathrm{H}), 4.17(\mathrm{~d}, J=4.0 \mathrm{~Hz}, 1 \mathrm{H}), 1.42(\mathrm{~d}, J=6.4 \mathrm{~Hz}, 3 \mathrm{H}) .{ }^{19} \mathrm{~F}$ NMR $(376 \mathrm{MHz}$, Acetone- $\left.d_{6}\right) \delta-63.05,-129.05$. HR-MS (ESI) calculated for $\mathrm{C}_{32} \mathrm{H}_{22} \mathrm{~F}_{4} \mathrm{~N}_{4} \mathrm{NaO}_{3}{ }^{+}: 609.1520 ; \mathrm{m} / \mathrm{z}$ found was $609.1519[\mathrm{M}+\mathrm{Na}]^{+}$; rt $13.91 \mathrm{~min}, 98 \%$.

\section{4-(6-fluoro-3-oxo-1,3-dihydro-2H-pyrazolo[4,3-c]cinnolin-2-yl)- $N$-(piperidin-4-}

yl)benzamide (8a). Compound $8 \mathbf{a}$ was synthesised from $\mathbf{6 b}$ following the same experimental procedure like the synthesis of $\mathbf{8 b}$ and as described in the supplementary part of a previous publication. ${ }^{6}$

4-(6-fluoro-3-oxo-4-(3-(trifluoromethyl)phenyl)-1,3-dihydro-2H-pyrazolo[4,3-c]quinolin-2yl)- $N$-(piperidin-4-yl)benzamide (8b). $16 \mathrm{mg}(0.034 \mathrm{mmol})$ of 6 e were dissolved in $350 \mu \mathrm{L} \mathrm{2:1}$ DMF/THF. Afterwards, $8.0 \mathrm{mg}(0.041 \mathrm{mmol}) \mathrm{EDC} \cdot \mathrm{HCl}, 41 \mu \mathrm{L}(0.041 \mathrm{mmol}) \mathrm{HOBt}, 30 \mu \mathrm{L}$ (0.171 mmol) DIPEA and $17.1 \mathrm{mg}(0.086 \mathrm{mmol})$ tert-butyl 4-aminopiperidine-1-carboxylate were added in this respective order. The reaction was run for $22.5 \mathrm{~h}$ at room temperature. The mixture was quenched with EtOAc and $\mathrm{H}_{2} \mathrm{O}$, and partitioned. The organic layers were dried over sodium sulfate and concentrated, resulting in a crude weight of $51.1 \mathrm{mg}$. Flash chromatography (1:1 Hexane:EtOAc $+0.5 \%$ Acetic Acid) was performed for purification. After drying the product three times with toluene, the weight of the intermediate was $20.1 \mathrm{mg}$. The intermediate was then dissolved and stirred in DCM with 20\% TFA for $1 \mathrm{~h}$ before concentrating under reduced pressure. DCM and acidified water was added and an extraction was performed once. The water phase was neutralised with aqueous $25 \% \mathrm{NH}_{3}$ solution and extraction with EtOAc was performed (5x). After concentration under reduced pressure, this resulted in a product weight of $10.7 \mathrm{mg}$ ( $70 \%$ yield). 
${ }^{1} \mathrm{H}$ NMR (400 MHz, Methanol-d $\left.d_{4}\right) \delta 8.22(\mathrm{~s}, 1 \mathrm{H}), 8.17(\mathrm{~d}, J=8.9 \mathrm{~Hz}, 2 \mathrm{H}), 8.13(\mathrm{~d}, J=7.8 \mathrm{~Hz}$, 1H), $8.11-8.08(\mathrm{~m}, 1 \mathrm{H}), 7.96(\mathrm{~d}, J=7.8 \mathrm{~Hz}, 1 \mathrm{H}), 7.85(\mathrm{~d}, J=8.9 \mathrm{~Hz}, 2 \mathrm{H}), 7.79$ (t, $J=7.8 \mathrm{~Hz}$, $1 \mathrm{H}), 7.54-7.47(\mathrm{~m}, 1 \mathrm{H}), 7.46-7.38(\mathrm{~m}, 1 \mathrm{H}), 4.21-4.11(\mathrm{~m}, 1 \mathrm{H}), 3.52-3.44(\mathrm{~m}, 2 \mathrm{H}), 3.20-$ $3.10(\mathrm{~m}, 2 \mathrm{H}), 2.25-2.16(\mathrm{~m}, 2 \mathrm{H}), 1.94-1.82(\mathrm{~m}, 2 \mathrm{H}) .{ }^{13} \mathrm{C}$ NMR (101 MHz, Methanol- $\left.d_{4}\right) \delta$ $169.2,163.2,155.2,153.6,152.7,145.0,143.6,138.9,135.1,131.6,131.2,130.2,129.9,129.2$ 128.2, 126.3, 121.9, 120.4, 119.2, 116.8, 116.6, 46.4, 44.4, 29.5. ${ }^{19} \mathrm{~F}$ NMR (376 MHz, Methanol$\left.d_{4}\right) \delta-63.92,-128.25$. HR-MS (MADLI/ESI) calculated for $\mathrm{C}_{29} \mathrm{H}_{24} \mathrm{~F}_{4} \mathrm{~N}_{5} \mathrm{O}_{2}{ }^{+}: 550.1861 ; m / z$ found was $550.1861[\mathrm{M}+\mathrm{H}]^{+}$.

Radiosynthesis of $\left[{ }^{11} \mathbf{C}\right] \mathbf{1}$ and $\left[{ }^{11} \mathbf{C}\right] \mathbf{7 f}$. The radiotracers were synthesized as shown in Scheme 4 and as recently described for $\left[{ }^{11} \mathrm{C}\right] \mathbf{1}$, with slight modifications. ${ }^{6}\left[{ }^{11} \mathrm{C}\right] \mathrm{CO}_{2}$ was produced by proton bombardment of nitrogen gas fortified with $0.5 \%$ oxygen in a Cyclone $18 / 9$ cyclotron $(18-\mathrm{MeV}$; IBA, Ottignies-Louvain-la-Neuve, Belgium) via the ${ }^{14} \mathrm{~N}(\mathrm{p}, \mathrm{a}){ }^{11} \mathrm{C}$ nuclear reaction. In a first step, nickel-based catalytic reduction of $\left[{ }^{11} \mathrm{C}\right] \mathrm{CO}_{2}$ yielded $\left[{ }^{11} \mathrm{C}\right]$ methane which was subsequently iodinated to give $\left[{ }^{11} \mathrm{C}\right] \mathrm{MeI}$. The $\left[{ }^{11} \mathrm{C}\right] \mathrm{MeI}$ was bubbled into a solution of $1.0 \mathrm{mg}$ precursor $(\mathbf{8 a}$ for $\left[{ }^{11} \mathrm{C}\right] \mathbf{1}$ and $\mathbf{8 b}$ for $\left[{ }^{11} \mathrm{C}\right] 7 \mathbf{f}$, respectively) in $0.6 \mathrm{~mL}$ DMF and $5 \mathrm{mg}$ cesium carbonate. The mixture was stirred at $90^{\circ} \mathrm{C}$ for $4 \mathrm{~min}$. After dilution of the reaction with $1.6 \mathrm{~mL} 50 \mathrm{mM}$ sodium acetate, the crude solution was purified by semi-preparative HPLC. The radiotracer was collected into $10 \mathrm{~mL}$ water and passed through a $\mathrm{C} 18$ cartridge. After washing with $5 \mathrm{~mL}$ water, the radiotracer was eluted with $0.5 \mathrm{~mL}$ ethanol into a sterile vial and diluted with $9.5 \mathrm{~mL}$ sterile $0.9 \% \mathrm{NaCl}$ solution. For quality control, $100 \mu \mathrm{L}$ of the final formulation was injected into the analytical HPLC system. Identity of the product was confirmed by comparison with the retention time of the 
standard reference. The molar activity was calculated from the linear regression of a UV-intensity based calibration curve of the cold reference. 
Scheme 4. Radiosynthesis of $\left[{ }^{11} \mathrm{C}\right] 7 \mathbf{f}$ from precursor $\mathbf{8 b}$.<smiles>O=C(NC1CCNCC1)c1ccc(-n2nc3c4cccc(F)c4[nH]c(-c4cccc(C(F)(F)F)c4)c-3c2=O)cc1</smiles>

$8 b$

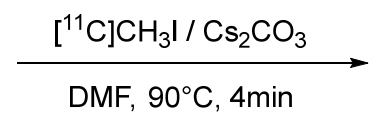

Radiosynthesis of $\left[{ }^{11} \mathbf{C}\right] 7 \mathbf{f}$. Radiotracer $\left[{ }^{11} \mathrm{C}\right] \mathbf{7 f}$ was prepared with precursor $(\mathbf{8 b})$ according to the above described radiosynthetic strategy of $\left[{ }^{11} \mathrm{C}\right] 1{ }^{6}$

Lipophilicity and lipid bilayer permeability. $\left[{ }^{11} \mathrm{C}\right] 7 \mathbf{f}(6 \mathrm{MBq}$ in $20 \mu \mathrm{l})$ was mixed for $30 \mathrm{~min}$ in triplicates with $0.5 \mathrm{~mL}$ PBS-saturated 1-octanol and 0.5 mL PBS adjusted to $\mathrm{pH}$ 5.4, 7.4, 9.0 and 11.0, respectively. After centrifugation, $100 \mu \mathrm{L}$ of each phase was measured in a gammacounter (Wizard, PerkinElmer) and $\log D$ was calculated as the logarithmic ratio between the 1-octanol and buffer phase. The data was analysed by non-linear regression with Equation 1:

$$
D=\frac{P_{\mathrm{i}}}{1+10^{\wedge}\left(\mathrm{pK}_{\mathrm{a}}-\mathrm{pH}\right)}+\frac{P_{\mathrm{n}}}{1+10^{\wedge}\left(\mathrm{pH}-\mathrm{pK}_{\mathrm{a}}\right)} \quad \text { Eq. } 1
$$

where $P_{\mathrm{i}}$ and $P_{\mathrm{n}}$ are the lower and upper plateaux of the function, i.e., $P$ of the ionised and neutral species, respectively. The $\log P$ corresponds to the logarithmic $P_{\mathrm{n}}$. 
Lipid bilayer permeability $\left(P_{\text {FLipP }}\right)$ was determined according to Hermann et al. ${ }^{18}$ with unilamellar 1-palmitoyl-2-oleoyl-sn-glycero-3-phosphocholine liposomes in $20 \mathrm{mM}$ 3-morpholinopropanesulfonic acid/190 mM NaCl at $\mathrm{pH} 7.4$.

SPR affinity and displacement assays. The SPR affinity assay was performed using a high capacity amine chip with a dextran surface, which was activated using 1-ethyl-3-(3dimethylaminopropyl)carbodiimid and $N$-hydroxysuccinimid (EDC/NHS) and subsequently coated with recombinant human CD80. The protein coated chip was kept under a steady flow of running buffer $(25 \mathrm{mM}$ Tris, $150 \mathrm{mM} \mathrm{NaCl}$, pH 7.2, containing 0.01\% TWEEN® 20 and 5\% DMSO). The analytes were diluted with running buffer from a micromolar to a subnanomolar concentration range. For the measurement, $100 \mu \mathrm{L}$ of each dilution was injected with an injection rate of $25 \mu \mathrm{L} / \mathrm{min}$.

The SPR displacement assay was performed using an amine chip with a dextran surface, which was activated using EDC/NHS and subsequently coated with rhCD80, rmCD80 or rhCD86. The protein coated chip was kept under a steady flow of running buffer. The analytes were diluted with $2 \mathrm{nM}$ rhCTLA-4 or $50 \mathrm{nM}$ rhCD28 solutions in running buffer ( $25 \mathrm{mM}$ Tris, $150 \mathrm{mM} \mathrm{NaCl}$, $\mathrm{pH}$ 7.2, containing $0.01 \% \mathrm{TWEEN} 囚 20$ and $2.5 \% \mathrm{DMSO}$ ), from a micromolar to a subnanomolar concentration range. For the measurement, $100 \mu \mathrm{L}$ of each dilution was injected with an injection rate of $25 \mu \mathrm{L} / \mathrm{min}$.

All SPR experiments were carried out on a Sierra SPR-2 device (Sierra Sensors, Hamburg, Germany). Data were analysed with the software Sierra Analyser (version 3.1.10.0). The Scrubber software (version 2.0c, BioLogic Software, Canberra, Australia) revealed similar results (data not 
shown). $K_{\mathrm{i}}$ values were estimated from the $\mathrm{IC}_{50}$ value, the $K_{\mathrm{d}}$ and the concentration of the displaced ligand, according to the Cheng-Prusoff equation. ${ }^{25}$

Plasma protein binding. For the evaluation of plasma protein binding, $0.5-1 \mathrm{MBq}$ radiotracer was added per $150 \mu \mathrm{L}$ plasma. The samples were incubated at room temperature for $10 \mathrm{~min}$. To each $150 \mu \mathrm{L}$ radiotracer-plasma solution was added $300 \mu \mathrm{L}$ ice-cold PBS and all samples were briefly vortexed. The samples were centrifuged at $14^{\prime} 000 \mathrm{x}$ g in Amicon ${ }^{\circledR}$ Centrifugal Filters with a size cutoff of $10 \mathrm{kDa}$ for $15 \mathrm{~min}$ at $4^{\circ} \mathrm{C}$. The filters were then inverted and briefly centrifuged at $200 \mathrm{x}$ $\mathrm{g}$ for $3 \mathrm{~min}$ to obtain the protein fraction. The radioactivity in Becquerel of the protein fraction $\left(A_{\text {protein }}\right)$, filtrate and filter unit were measured in a gammacounter (Wizard, PerkinElmer), $A_{\text {total }}$ was calculated as the sum of these radioactivities, and the free fraction $f_{\mathrm{u}}$ was calculated according to equation 2:

$$
f_{\mathrm{u}}=1-\frac{A_{\text {protein }}}{A_{\text {total }}} \quad \text { Eq. } 2
$$

Animal xenograft model and PET/CT. Raji cells (DSMZ, Braunschweig, Germany) were cultured according to the supplier's recommendation. For inoculations, $2 \times 10^{6}$ Raji cells were mixed with $100 \mu \mathrm{L}$ Matrigel (Corning Inc, US) and subcutaneously injected in the right shoulder of SCID mice. PET/CT scans were performed 10 to 15 days after inoculation when the tumor volume was between 1.25 and $1.76 \mathrm{~cm}^{3}$. For PET/CT imaging, mice were anesthetized by inhalation of $2-5 \%$ isoflurane. Respiratory rate and body temperature were controlled as described elsewhere. ${ }^{6}\left[{ }^{11} \mathrm{C}\right] 7 \mathbf{f}(5-12 \mathrm{MBq}, 13-19 \mathrm{nmol} / \mathrm{kg})$ was injected intravenously into the tail vein and a 
dynamic PET scan was run from 1 to 61 min post-injection with a subsequent CT scan, both on a Super Argus PET/CT (Sedecal S.A., Madrid, Spain). Note that the same data sets were used in our previous publication where details on data reconstruction are available. ${ }^{19}$ The reconstructed PET/CT data were analysed using PMOD software (PMOD, Zurich, Switzerland; version 3.8). Tissue radioactivity was expressed as standardized uptake values (SUV), which is the decaycorrected image-derived radioactivity per $\mathrm{cm}^{3}$ tissue (multiplied with $1 \mathrm{~g} / \mathrm{cm}^{3}$ ), divided by the injected radioactivity dose per gram of body weight.

In vivo metabolism of $\left[{ }^{11} \mathbf{C}\right] 7 \mathbf{f}$. $\left[{ }^{11} \mathrm{C}\right] 7 \mathbf{f}(55-74 \mathrm{MBq})$ was injected intravenously in three 15-16 weeks old male C57BL/6 mice. The mice were decapitated under isoflurane anaesthesia 15 min (2 animals) and 60 min (1 animal) after tracer injection and blood, bile and urine were collected. Plasma was separated by centrifugation $\left(1000 \mathrm{x}\right.$ g for $5 \mathrm{~min}$ at $\left.4^{\circ} \mathrm{C}\right)$ and proteins were denatured with an equal volume of $\mathrm{MeCN}$ on ice. After precipitation of the denatured proteins by centrifugation, the filtrated supernatants were analysed by UHPLC. Bile and urine were mixed with equal volumes of MeCN and filtrated for analysis by UHPLC. At 60 min post injection the signal-to-noise ratio in plasma and urine were too low for evaluation.

Single-crystal X-ray diffraction. Structure was refined with SHELXL-2018/3 and SHELXLE ${ }^{26,27}$ Figure S10 was created with PLATON. ${ }^{28}$ Data were collected at beamline PXI at the Swiss Light Source, PSI. See CIF file for further details. CIF file deposited with CCDC number 1937859. 
Statistical analysis. Data were statistically evaluated with student's $t$ test and non-linear curve fitting with GraphPad Prism Software (Version 7.02, GraphPad Software Inc.) for IC50 or Excel Solver (Microsoft Office 2016) for $\log D$. 


\section{ANCILLARY INFORMATION}

\section{Supporting Information Availability}

The Supporting Information is available free of charge on the ACS Publications website at http://pubs.acs.org.

- Molecular formula strings (CSV)

- Supporting material (PDF) containing:

$\circ$ [S1] SPR sensorgrams of the binding of $\mathbf{1}$ and $\mathbf{7} \mathbf{f}$ to hCD80

$\circ$ [S2] SPR displacement of abatacept by compound $7 \mathbf{f}$ on hCD86

○ [S3] SPR displacement of abatacept by compound $7 \mathbf{f}$ on mCD80

$\circ[\mathrm{S} 4] \mathrm{pH}-$ Dependent distribution of $\left[{ }^{11} \mathrm{C}\right] 7 \mathbf{f}$ between 1-octanol and PBS

○ [S5] Autoradiography with hCD80-positive \& -negative xenograft slices with $\left[{ }^{11} \mathrm{C}\right] 7 \mathbf{f}$

○ [S6] Quantification of autoradiographic experiment with $\left[{ }^{11} \mathrm{C}\right] 7 \mathbf{f}$

○ [S7] Cell surface expression of hCD80, hCD86 and hCTLA-4 by flow cytometry

○ [S8] mRNA expression levels of hCD80/hCTLA-4/hCD28 in Raji and NCI xenografts

○ [S9] UHPLC chromatograms of in vivo samples from mice 15 min after $\left[{ }^{11} \mathrm{C}\right] 7 \mathbf{f}$ injection

○ [S10] Crystal data and structure refinement for compound $\mathbf{7 f}$

\section{Corresponding Authors Information}

Marco F. Taddio: $\quad$ marco.taddio@alumni.ethz.ch

Stefanie D. Krämer: stefanie.kraemer@pharma.ethz.ch

\section{Acknowledgments}

The authors thank Bruno Mancosu and Claudia Keller for their great technical support and their commitment with the radiotracer synthesis and subsequent animal studies and Peter Runge and 
Cornelia Halin for their great support with the flow cytometry. This work was supported by the Swiss National Science Foundation (SNSF) [153352 and 179238] and by the KFSP Molecular Imaging Network Zurich (MINZ).

\section{Abbrebiations used}

$\mathrm{Bq}$, becquerel; CT, computed tomography; CTLA-4, cytotoxic T-lymphocyte-associated protein 4; DIPEA, N,N-diisopropylethylamine; EDC, 1-ethyl-3-(3-dimethylaminopropyl)carbodiimide; EtOAc, ethyl acetate; EtOH, ethanol; FDG, fludeoxyglucose; HATU, 1[bis(dimethylamino)methylene]-1H-1,2,3-triazolo[4,5-b]pyridinium 3-oxid hexafluorophosphate; HR-MS, high resolution mass spectrometry; HOBt, hydroxybenzotriazole; $K_{\mathrm{d}}$, dissociation constant; kDa, kilodalton; $\mathrm{MeCN}$, acetonitrile; $\mathrm{MeOH}$, methanol; NHS, $N$-hydroxysuccinimide; RT-qPCR, real-time polymerase chain reaction; SPR, surface plasmon resonance; SUV, standardized uptake value. 


\section{REFERENCES}

(1) Tivol, E. A.; Borriello, F.; Schweitzer, A. N.; Lynch, W. P.; Bluestone, J. A.; Sharpe, A.

H. Loss of CTLA-4 Leads to Massive Lymphoproliferation and Fatal Multiorgan Tissue Destruction, Revealing a Critical Negative Regulatory Role of CTLA-4. Immunity 1995, 3 (5), 541-547. https://doi.org/10.1016/1074-7613(95)90125-6.

(2) Chen, L.; Flies, D. B. Molecular Mechanisms of T Cell Co-Stimulation and Co-Inhibition. Nature Reviews Immunology. 2013, pp 227-242. https://doi.org/10.1038/nri3405.

(3) Schietinger, A.; Greenberg, P. D. Tolerance and Exhaustion: Defining Mechanisms of T Cell Dysfunction. Trends in Immunology. 2014, pp 51-60. https://doi.org/10.1016/j.it.2013.10.001.

(4) Seliger, B.; Marincola, F. M.; Ferrone, S.; Abken, H. The Complex Role of B7 Molecules in Tumor Immunology. Trends in Molecular Medicine. 2008, pp 550-559. https://doi.org/10.1016/j.molmed.2008.09.010.

(5) Dietel, B.; Altendorf, R.; Cicha, I.; Garlichs, C. Migration of Regulatory T Cells into Human Atherosclerotic Lesions Is Associated with Plaque Stability and Correlates Inversely with Infiltrated Mature Dendritic Cells. Eur. Heart J. 2013, 34, 441

(6) Müller, A.; Mu, L.; Meletta, R.; Beck, K.; Rancic, Z.; Drandarov, K.; Kaufmann, P. A.; Ametamey, S. M.; Schibli, R.; Borel, N.; Krämer, S. D. Towards Non-Invasive Imaging of Vulnerable Atherosclerotic Plaques by Targeting Co-Stimulatory Molecules. Int. J. Cardiol. 2014, 174 (3), 503-515. https://doi.org/10.1016/j.ijcard.2014.04.071.

(7) Adams, A. B.; Ford, M. L.; Larsen, C. P. Costimulation Blockade in Autoimmunity 
Costimulation Blockade in Autoimmunity and Transplantation: The CD28 Pathway. J Immunol 2016, 197 (6), 2045-2050. https://doi.org/10.4049/jimmunol.1601135.

(8) Biancone, L.; Segoloni, G.; Turello, E.; Donati, D.; Bussolati, B.; Piccoli, G.; Camussi, G. Expression of Inducible Lymphocyte Costimulatory Molecules in Human Renal Allograft. Nephrol. Dial. Transplant 1998, 13 (3), 716-722.

(9) Kremer, J. M.; Westhovens, R.; Leon, M.; Di Giorgio, E.; Alten, R.; Steinfeld, S.; Russell, A.; Dougados, M.; Emery, P.; Nuamah, I. F.; Williams, G. R.; Becker, J. C.; Hagerty, D. T.; Moreland, L. W. Treatment of Rheumatoid Arthritis by Selective Inhibition of T-Cell Activation with Fusion Protein CTLA4Ig. N. Engl. J. Med. 2003, 349 (20), 1907-1915. https://doi.org/10.1056/nejmoa035075.

(10) Cutolo, M.; Nadler, S. G. Advances in CTLA-4-Ig-Mediated Modulation of Inflammatory Cell and Immune Response Activation in Rheumatoid Arthritis. Autoimmunity Reviews. 2013, pp 758-767. https://doi.org/10.1016/j.autrev.2013.01.001.

(11) Larsen, C. P.; Pearson, T. C.; Adams, A. B.; Tso, P.; Shirasugi, N.; Strobert, E.; Anderson, D.; Cowan, S.; Price, K.; Naemura, J.; Emswiler, J.; Greene, J.; Turk, L. A.; Bajorath, J.; Townsend, R.; Hagerty, D.; Linsley, P. S.; Peach, R. J. Rational Development of LEA29Y (Belatacept), a High-Affinity Variant of CTLA4-Ig with Potent Immunosuppressive Properties. Am. J. Transplant. 2005, 5 (3), 443-453. https://doi.org/10.1111/j.1600-6143.2005.00749.x.

(12) Rostaing, L.; Vincenti, F.; Grinyõ, J.; Rice, K. M.; Bresnahan, B.; Steinberg, S.; Gang, S.; Gaite, L. E.; Moal, M. C.; Mondragõn-Ramirez, G. A.; Kothari, J.; Pupim, L.; Larsen, C. P. LongTerm Belatacept Exposure Maintains Efficacy and Safety at 5 Years: Results from the Long-Term Extension of the BENEFIT Study. Am. J. Transplant. 2013, 13 (11), 2875-2883. 
https://doi.org/10.1111/ajt.12460.

(13) Erbe, D. V.; Wang, S.; Xing, Y.; Tobin, J. F. Small Molecule Ligands Define a Binding Site on the Immune Regulatory Protein B7.1. J. Biol. Chem. 2002, 277 (9), 7363-7368. https://doi.org/10.1074/jbc.M110162200.

(14) Green, N. J.; Xiang, J.; Chen, J.; Chen, L.; Davies, A. M.; Erbe, D.; Tam, S.; Tobin, J. F. Structure-Activity Studies of a Series of dipyrazolo[3,4-b:3',4'-d]pyridin-3-Ones Binding to the Immune Regulatory Protein B7.1. Bioorganic Med. Chem. 2003, 11 (13), 2991-3013. https://doi.org/10.1016/S0968-0896(03)00183-4.

(15) Huxley, P.; Sutton, D. H.; Debnam, P.; Matthews, I. R.; Brewer, J. E.; Rose, J.; Trickett, M.; Williams, D. D.; Andersen, T. B.; Classon, B. J. High-Affinity Small Molecule Inhibitors of T Cell Costimulation: Compounds for Immunotherapy. Chem. Biol. 2004, 11 (12), 1651-1658. https://doi.org/10.1016/j.chembiol.2004.09.011.

(16) Uvebrant, K.; Da, D.; Thrige, G.; Rosén, A.; Åkesson, M.; Berg, H.; Walse, B.; Björk, P. Discovery of Selective Small-Molecule CD80 Inhibitors. J. Biomol. Screen. 2007, 12 (4), 464472. https://doi.org/10.1177/1087057107300464.

(17) Li, K.; Cheng, X.; Tilevik, A.; Davis, S. J.; Zhu, C. In Situ and in Silico Kinetic Analyses of Programmed Cell Death-1 (PD-1) Receptor, Programmed Cell Death Ligands, and B7-1 Protein Interaction Network. J. Biol. Chem. 2017, 292 (16), 6799-6809. https://doi.org/10.1074/jbc.M116.763888.

(18) Hermann, K. F.; Neuhaus, C. S.; Micallef, V.; Wagner, B.; Hatibovic, M.; Aschmann, H. E.; Paech, F.; Alvarez-Sanchez, R.; Krämer, S. D.; Belli, S. Kinetics of Lipid Bilayer Permeation 
of a Series of Ionisable Drugs and Their Correlation with Human Transporter-Independent Intestinal Permeability. Eur. J. Pharm. Sci. 2017, 104, 150-161. https://doi.org/10.1016/j.ejps.2017.03.040.

(19) Taddio, M. F.; Mu, L.; Keller, C.; Schibli, R.; Krämer, S. D. Physiologically Based Pharmacokinetic Modelling with Dynamic PET Data to Study the in Vivo Effects of Transporter Inhibition on Hepatobiliary Clearance in Mice. Contrast Media Mol. Imaging 2018, Article ID 5849047. https://doi.org/10.1155/2018/5849047.

(20) Paxton, J. W. Alpha1-Acid Glycoprotein and Binding of Basic Drugs. Methods and Findings in Experimental and Clinical Pharmacology. 1983, pp 635-648.

(21) Neef, C.; Meijer, D. K. F. Structure-Pharmacokinetics Relationship of Quaternary Ammonium Compounds. Naunyn. Schmiedebergs. Arch. Pharmacol. 2004, 328 (2), 111-118. https://doi.org/10.1007/bf00512059.

(22) Jonker, J. W.; Wagenaar, E.; Mol, C. A. A. M.; Buitelaar, M.; Koepsell, H.; Smit, J. W.; Schinkel, A. H. Reduced Hepatic Uptake and Intestinal Excretion of Organic Cations in Mice with a Targeted Disruption of the Organic Cation Transporter 1 (Oct1 [Slc22a1]) Gene. Mol. Cell. Biol. 2001, 21 (16), 5471-5477. https://doi.org/10.1128/MCB.21.16.5471.

(23) Urien, S.; Tillement, J.-P. pH-Dependency of Basic Ligand Binding to alpha1-Acid Glycoprotein (Orosomucoid). Biochem. $\quad J . \quad 1991, \quad 280, \quad 277-280$. https://doi.org/10.1042/bj2800277.

(24) Huang, Z.; Ung, T. Effect of Alpha-1-Acid Glycoprotein Binding on Pharmacokinetics and Pharmacodynamics. Curr. Drug Metab. 2013, 14 (2), 226-238. 
(25) Yung-Chi, C.; Prusoff, W. H. Relationship between the Inhibition Constant (KI) and the Concentration of Inhibitor Which Causes 50 per Cent Inhibition (I50) of an Enzymatic Reaction. Biochem. Pharmacol. 1973, 22 (23), 3099-3108. https://doi.org/10.1016/0006-2952(73)90196-2.

(26) Sheldrick, G. M. Crystal Structure Refinement with SHELXL. Acta Crystallogr. Sect. C Struct. Chem. 2015, 71, 3-8. https://doi.org/10.1107/S2053229614024218.

(27) Hübschle, C. B.; Sheldrick, G. M.; Dittrich, B. ShelXle: A Qt Graphical User Interface for SHELXL. J. Appl. Crystallogr. 2011, $44 \quad$ (6), 1281-1284. https://doi.org/10.1107/S0021889811043202.

(28) Spek, A. L. PLATON SQUEEZE: A Tool for the Calculation of the Disordered Solvent Contribution to the Calculated Structure Factors. Acta Crystallogr. Sect. C Struct. Chem. 2015, 71, 9-18. https://doi.org/10.1107/S2053229614024929. 